\title{
Catalytic performance of binary and ternary oxovanadium complexes of dipyridinyl-urea in (ep)oxidation of cis-cyclooctene and 1-octene
}

\author{
Mohamed Shaker S. Adam ${ }^{1,2} \cdot$ Aly M. Hafez ${ }^{1}$ Ibrahim El-Ghamry ${ }^{1}$
}

Received: 9 February 2018/Accepted: 17 March 2018/Published online: 21 March 2018

(C) The Author(s) 2018

\begin{abstract}
Two novel ternary and binary mono-oxovanadium(IV) complexes of acetylacetonate (ac) and 1,3-dipyridin-2-yl-urea are synthesized, as VO(acac)(L) (1:1) and $\mathrm{VO}(\mathrm{L})_{2}(1: 2)$. They are characterized by various physico-chemical spectroscopic tools. The formation constants $K_{f}$ are calculated from the spectrophotometric measurements. The catalytic potential of $\mathrm{VO}(\mathrm{acac})(\mathrm{L})$ and $\mathrm{VO}(\mathrm{L})_{2}$ has been examined in the (ep)oxidation of alkenes (cis-cyclooctene and 1-octene) by an aqueous hydrogen peroxide, $\mathrm{H}_{2} \mathrm{O}_{2}$, and tert-butyl hydroperoxide, TBHP. The effects of temperature, solvent and oxidant/alkene molar ratio are studied in order to get the optimized reaction conditions. Most of the catalytic (ep)oxidation products of cis-cyclooctene and 1-octene are determined qualitatively and quantitatively using gas chromatographic analysis. The increase of the catalyst amount to double time reduces the (ep)oxidation process time with improvement of the amount of the chemoselective epoxy product.
\end{abstract}

Keywords Oxovanadium(IV) - Dipyridinyl-urea $\cdot$ Catalysis $\cdot$ Oxidation $\cdot$ cisCyclooctene $\cdot 1$-Octene $\cdot$ Organometallic-vanadium intermediate

Electronic supplementary material The online version of this article (https://doi.org/10.1007/s11144018-1399-8) contains supplementary material, which is available to authorized users.

Mohamed Shaker S. Adam

madam@kfu.edu.sa; shakeradam61@yahoo.com

1 Department of Chemistry, College of Science, King Faisal University, P.O. Box 380, Al Hufuf 31982, Al Hassa, Saudi Arabia

2 Department of Chemistry, Faculty of Science, Sohag University, Sohag 82534, Egypt 


\section{Introduction}

Oxovanadium complexes are very important class of high valent $3 \mathrm{~d}$ transition metal complexes which attracted attention in therapeutic and medicinal immense [1], as anti-cancers [2], anti-diabetes [3] and speciation in human serum [4]. High progressed applicability of oxovanadium complexes is in the (ep)oxidation of organic substrates $[5,6]$. They are high effective and selective catalysts for many homogeneous and heterogeneous oxidation processes of unsaturated hydrocarbons [7-9]. Indeed, vanadium ion features various oxidation states, especially accessible high oxidation states, i.e. oxovanadium(IV), with different coordination modes and a high affinity for oxygen, sulfur and nitrogen donation have been reported $[10,11]$.

The coordination chemical behavior of 1,3-dipyridin-2-yl-urea, and their derivatives with various first row of transition metals is of interest due to the presence of $\mathrm{O}, \mathrm{N}$-donor atoms [12] and/or participation in intramolecular hydrogenbonding interactions [13, 14]. Kyriakidou et al. [15], studied the coordination behavior of 1,3-dipyridylurea with $\mathrm{Ni}^{2+}$ ion in molar ratios 1 (metal):3 (ligand), whereas, Tiliakos et al. [16] reported the complexation of $\mathrm{Ni}^{2+}$ with 1,3dipyridylurea was $1: 2$ with coordination of two nitrate ions to $\mathrm{Ni}^{2+}$ ion in the molecular structure. Furthermore, their possible behavior as polydentate deprotonated ligands also lead to dianionic ligands and forming polynuclear complexes as observed previously in the complexation of ruthenium with 1,3-dipyridylurea [12].

Therefore, due to the aforementioned importance and in continuation of our work [11], two novel VO-complexes of $\mathrm{VO}^{2+}$ ions with 1,3-dipyridin-2-yl-urea are synthesized and characterized. Additionally, their catalytic potential is examined in the (ep)oxidation of cis-cyclooctene and 1-octene by either an aqueous $\mathrm{H}_{2} \mathrm{O}_{2}$ or TBHP as terminal oxidants under various reaction conditions to establish their catalytic potentials and the optimized catalytic conditions.

\section{Experimental}

\section{Instruments and reagents}

All required reagents and materials are purchased from Sigma-Aldrich and Fluka, which directly used without any further purifications or treatment. Elemental analyses ( $\mathrm{C}, \mathrm{H}$ and $\mathrm{N}$ ) were achieved with a GMBH VarioEl model V2.3 CHNS machine. Electronic spectra were measured using $10 \mathrm{~mm}$ silica cells in the thermostatted cell holder of a Jasco UV-Vis spectrophotometer (model V-570). Infrared spectra (as KBr discs) were recorded in the region of $4000-400 \mathrm{~cm}^{-1}$ using Shimadzu FTIR-8101 Fourier transform infrared spectrophotometer. Conductivity measurements were carried out using a Jenway conductivity meter model 4320, with an epoxy bodied conductivity cell (two electrodes, shiny) with cell constant calibration from 0.01 to 19.99 at $25{ }^{\circ} \mathrm{C}$. Magnetic susceptibility of the studied complexes were measured on Gouy's balance, the diamagnetic correction were made by Pascal's contents and $\mathrm{Hg}\left[\mathrm{Co}(\mathrm{SCN})_{4}\right]$ as a calibrant. All experimental 
reactions were taken place with magnetic stirring and held at chosen temperatures using a thermostated oil bath.

\section{Synthesis of 1,3-dipyridin-2-yl-urea, HL}

1,3-Di-pyridin-2-yl-urea (HL) was synthesized according to the reported method with some modifications [15]. To a cooled solution (in ice-acetone bath) of nicotinic acid $(0.12 \mathrm{~g}, 1.0 \mathrm{mmol})$ and anhydrous triethylamine $(0.13 \mathrm{~mL}, 1.0 \mathrm{mmol})$ in absolute THF $(20 \mathrm{~mL})$ anhydrous ethylchloroformate $(0.10 \mathrm{~mL}, 1.0 \mathrm{mmol})$ was added dropwise with stirring. Then, a cold solution of 2-aminopyridine $(0.18 \mathrm{~g}$, $2.0 \mathrm{mmol})$ in absolute THF (10 $\mathrm{mL})$ was added and the solution was stirred at room temperature for $3 \mathrm{~h}$. The reaction mixture was evaporated under vacuum. The solid residue was extracted with dichloromethane and a solution of $5 \% \mathrm{Na}_{2} \mathrm{CO}_{3}$ was added under vigorous stirring. The organic phase was separated and dried over $\mathrm{Na}_{2} \mathrm{SO}_{4}$. The obtained residue after evaporation was recrystallized from ethanol to give the desired product as off white crystals in yield $60 \%\left({ }^{1} \mathrm{HNMR},{ }^{13} \mathrm{CNMR}\right.$ and dept-135, and mass spectra of HL are in Supplementary Information).

\section{Synthesis of oxovanadium complexes}

Synthesis of oxovanadium acetylacetonate 1,3-dipyridin-2-yl-urea complex, $\operatorname{VO}(\operatorname{acac})(L)$

A methanolic solution $(10 \mathrm{~mL})$ of 1,3-dipyridin-2-yl-urea $(0.21 \mathrm{~g}, 1.0 \mathrm{mmol})$ was added very slowly dropwisely to vanadyl acetylacetonate $(0.26 \mathrm{~g}, 1.0 \mathrm{mmol})$ in methanol $(10 \mathrm{~mL})$ in ice bath with stirring. No change in color (blue) was observed after mixing. The resulted solution was heated at $60{ }^{\circ} \mathrm{C}$ for $6 \mathrm{~h}$. The color of the solution changed gradually to pale green with no formation of any precipitate. After cooling, solvent was removed in vacuum and the residual washed further by cold methanol and diethyl ether and dried in vacuum. The pure complex was recrystallized from hot methanol to award $0.26 \mathrm{~g}$ (70\%) yield of pale greenish brown powder.

Synthesis of oxovanadium bis-1,3-dipyridin-2-yl-urea complex, $\mathrm{VO}(\mathrm{L})_{2}$

A methanolic solution $(10 \mathrm{~mL})$ of vanadyl acetylacetonate $(0.26 \mathrm{~g}, 1.0 \mathrm{mmol})$ was added dropwise to a methanolic mixture $(20 \mathrm{~mL})$ of 1,3-dipyridin-2-yl-urea $(0.46 \mathrm{~g}$, $2.0 \mathrm{mmol})$ and $\mathrm{KOH}(0.11 \mathrm{~g}, 2 \mathrm{mmol})$ at room temperature with noticed no change in color (blue) after mixing. Then, the reaction mixture was refluxed with stirring at $80{ }^{\circ} \mathrm{C}$ for $2 \mathrm{~h}$ affording changing in color to green with no formation of any precipitate. The solvent was removed in vacuum and the residual was washed with cold methanol, water and diethyl ether. The obtained complex was recrystallized from hot methanol yielding $0.41 \mathrm{~g}(78 \%)$ of green powder. 


\section{Catalytic procedures}

The catalytic oxidation of alkene (1.0 mmol, cis-cyclooctene or 1-octene) initiated by charging either $30 \%$ an aqueous $\mathrm{H}_{2} \mathrm{O}_{2}(3.0 \mathrm{mmol})$ or $70 \%$ in water of TBHP $(1.5 \mathrm{mmol})$, as the oxygen source, using VO-complexes as catalysts $(0.01 \mathrm{mmol})$ in $10 \mathrm{~mL}$ of acetonitrile or other organic solvent (chloroform, acetone, DMF or carbon tetrachloride), at various temperatures $\left(45,70\right.$ and $\left.85^{\circ} \mathrm{C}\right)$ in an oil bath under magnetic stirring for $16 \mathrm{~h}$ in an homogenous aerobic atmosphere. The catalytic processes were controlled by withdrawing samples (ca. $1 \mathrm{~mL}$ ) at different time intervals during the catalytic process. Collected samples were treated with solid $\mathrm{MnO}_{2}$ (ca. $20 \mathrm{mg}$ ) to quench the excess amounts an aqueous $\mathrm{H}_{2} \mathrm{O}_{2}$ or TBHP and with anhydrous sodium sulfate (ca. $20 \mathrm{mg}$ ), under the same conditions for each catalytic run. The resulting slurry was filtered on Celite, and the filtrate was diluted by acetonitrile (1:3) mixed in vortex and then $1 \mu \mathrm{L}$ of the sample was injected in the GC-MS.

The products of the catalytic processes were monitored and analyzed by Shimadzu gas chromatograph mass spectrometer (GC-MS) model QP2010 SE equipped with Rxi-5 Sil MS capillary column $(30 \mathrm{~m}$ length $\times 0.25 \mathrm{~mm}$ ID $\times 025$ um film thickness). The analysis was performed using the gas chromatography parameters as follow: injector temperature, $250{ }^{\circ} \mathrm{C}$; initial oven temperature, $40{ }^{\circ} \mathrm{C}$ (held for $1 \mathrm{~min}$ ), increased to $200{ }^{\circ} \mathrm{C}$ at a rate of $10{ }^{\circ} \mathrm{C} \mathrm{min}^{-1}$. The total time required for one $\mathrm{GC}$ run was $17 \mathrm{~min}$. The inlet was operated in the splitless mode. The MS transfer line was held at $200{ }^{\circ} \mathrm{C}$. The carrier gas is high-purity helium with a flow rate $1 \mathrm{~mL} \min ^{-1}$. LabSolution software was used to control the system and to acquire the analytical data. Peaks identification were made by comparing the mass spectra of detected compounds with NIST mass spectral library.

\section{Results and discussion}

\section{Synthesis and characterization of the oxovanadium complexes}

The synthesis of the VO-complexes carried out by the reaction of 1,3-dipyridin-2yl-urea (HL) with vanadyl acetylacetonate, $\mathrm{VO}(\mathrm{acac})_{2}$ in molar ratios 1:1 to afford $\mathrm{VO}(\operatorname{acac})(\mathrm{L})$ and 2:1 giving $\mathrm{VO}(\mathrm{L})_{2}$. They are soluble in DMSO and DMF. $\mathrm{VO}(\mathrm{acac})(\mathrm{L})$ is partial soluble in polar solvents, e.g. methanol, ethanol and acetone, whereas, $\mathrm{VO}(\mathrm{L})_{2}$ is insoluble in polar or less polar organic solvents, e.g. methanol, acetone, chloroform and dichloromethane. The $\mathrm{pH}$ stability range of VO-complexes solutions $\left(1.0 \times 10^{-3} \mathrm{~mol} \mathrm{dm}^{-3}\right.$ in DMSO $)$ is in the region from $\mathrm{pH} \sim 4.2$ to 9.4 using standard universal buffer solutions. They are unstable in strong basic and acidic media in which their color decays gradually. VO-complexes decompose at high temperatures $\left(>300{ }^{\circ} \mathrm{C}\right)$ as recorded in Table 1 .

The characteristic values of the VO-complexes are compared with those of the corresponding reported for complexes of 1,3-dipyridin-2-yl-thiourea [11] in order to confirm the coordination mode between $\mathrm{VO}^{2+}$ ion and $\mathrm{HL}$ ligand. The elemental microanalysis data of the VO-complexes are in good agreement $( \pm 0.4 \%)$ with their 


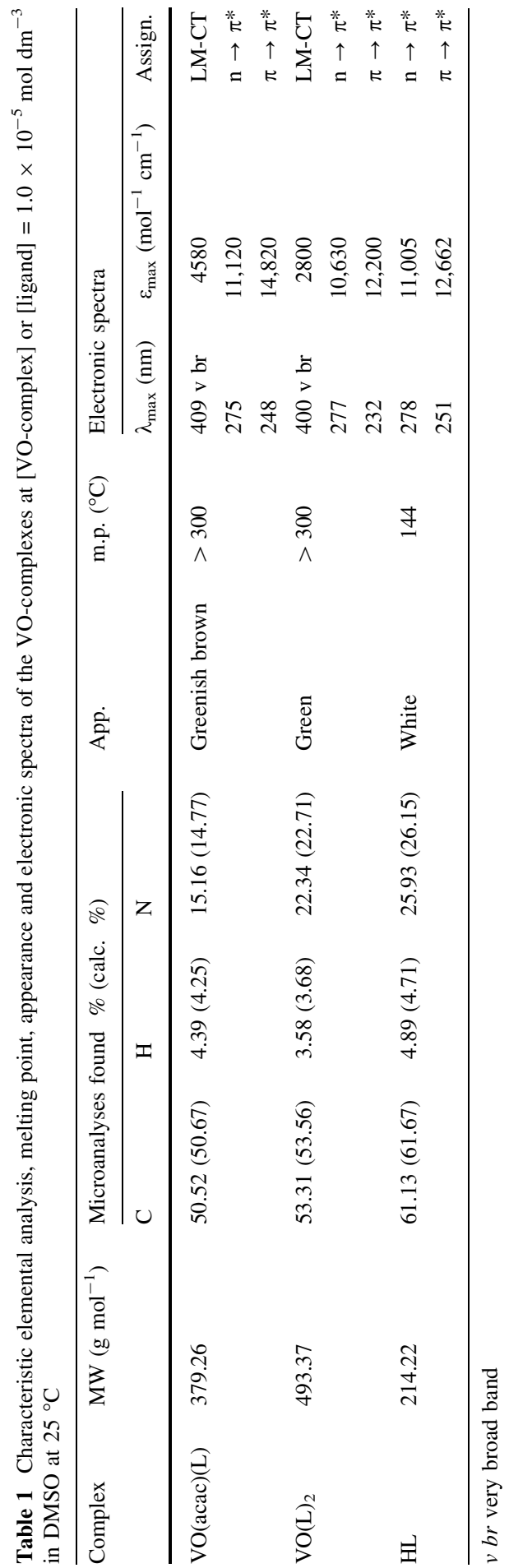


tentative molecular structures (Table 1). HL ligand in VO-complexes is acting as a chelating monobasic ligand in a monomeric structure with square pyramidal coordination geometry of the bis-binary complex, $\mathrm{VO}(\mathrm{L})_{2}$, and in the ternary complex, $\mathrm{VO}(\mathrm{acac})(\mathrm{L})$, as shown in Scheme 1.

The UV-Visible absorption spectra of HL and its corresponding VO-complexes are scanned at the wavelength range $700-200 \mathrm{~nm}$ at $25^{\circ} \mathrm{C}$ (Fig. 1). The maximum absorption wavelengths $\left(\lambda_{\max }\right)$ and the calculated molar absorptivity $(\varepsilon)$ are given in Table 1. An intense band in the range at 248 and $232 \mathrm{~nm}$ are assigned to a $\pi \rightarrow \pi^{*}$ transition originate in the aromatic moiety in $\mathrm{VO}(\mathrm{acac})(\mathrm{L})$ and $\mathrm{VO}(\mathrm{L})_{2}$, respectively. This band has been shifted in HL $(251 \mathrm{~nm})$ due to the effect of the presence of central metal ion due to the complexation. Additionally, an intense band at 275 and $277 \mathrm{~nm}$ for $\mathrm{VO}(\mathrm{acac})(\mathrm{L})$ and $\mathrm{VO}(\mathrm{L})_{2}$, respectively, is attributable for the $\mathrm{n} \rightarrow \pi^{*}$ transitions without any observable shift for that band in the free ligand HL

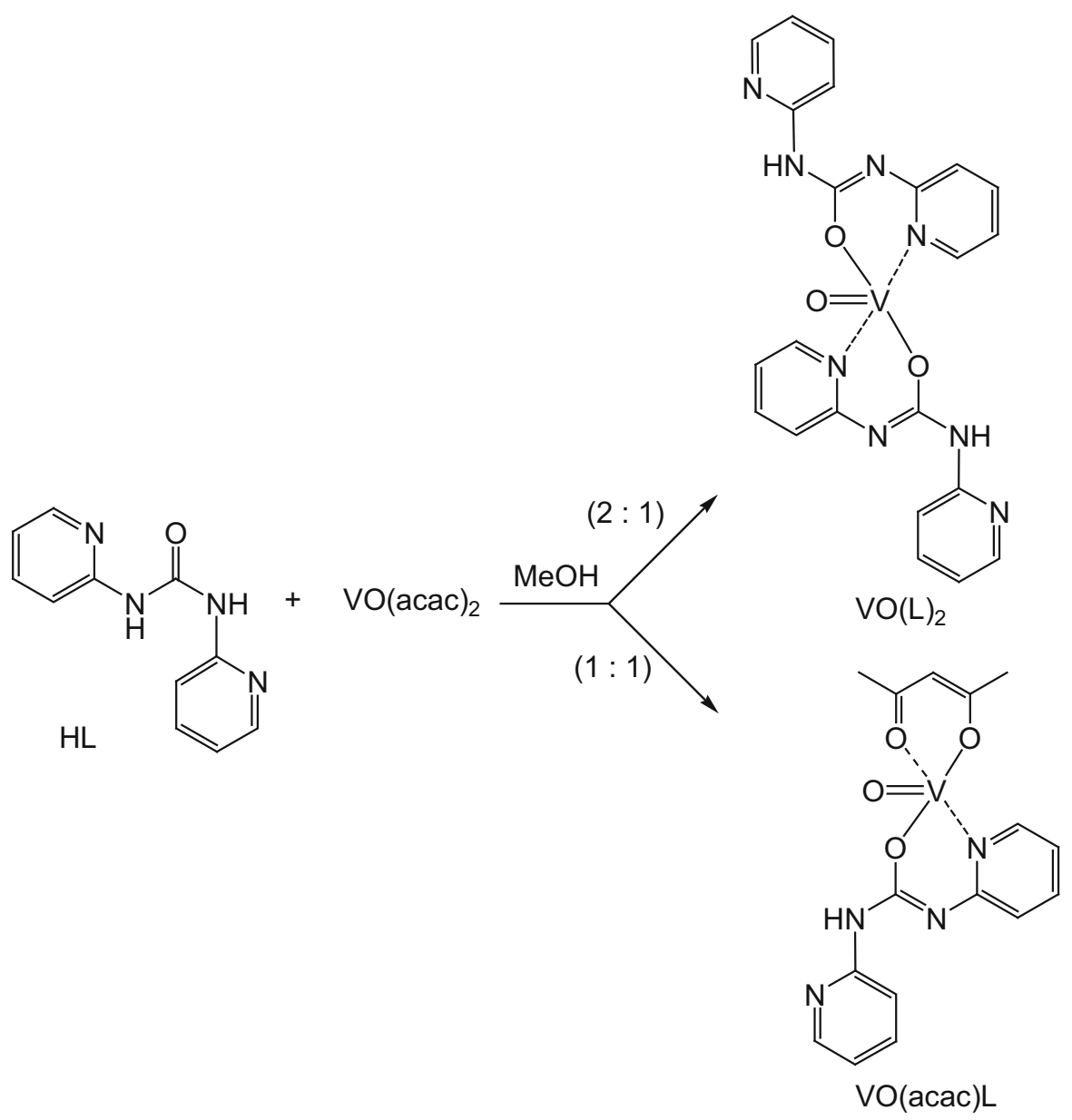

Scheme 1 The synthetic route and molecular structures of the VO-complexes 


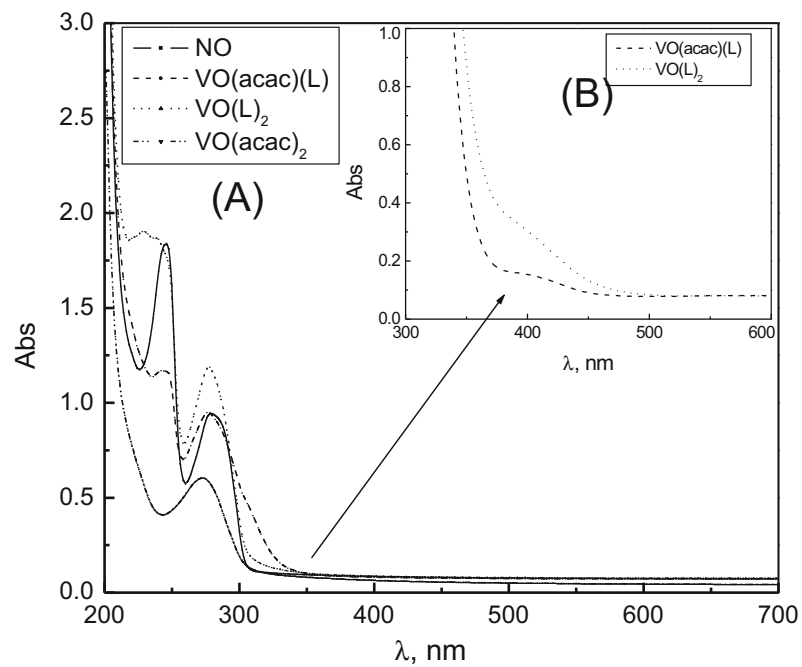

Fig. 1 a Molecular spectral scan of HL ligand and its corresponding VO-complexes and $\mathrm{VO}(\mathrm{acac})_{2}$, $\left[\right.$ complex] $=1.0 \times 10^{-5} \mathrm{~mol} \mathrm{dm}^{-3}$ in DMSO at $25^{\circ} \mathrm{C}$. b Molecular spectral scan zoom in of $\mathrm{VO}(\mathrm{acac})(\mathrm{L})$ and $\mathrm{VO}(\mathrm{L})_{2}$

(278 nm). A broad band shown at 409 and $400 \mathrm{~nm}$ for $\mathrm{VO}(\mathrm{acac})(\mathrm{L})$ and $\mathrm{VO}(\mathrm{L})_{2}$, respectively, could be attributed to the charge transfer from $\mathrm{HL}$ to $\mathrm{VO}^{2+}$ ion (Table 1). $\mathrm{L} \rightarrow$ MCT transition might arise due to a charge transfer from a negative charge on oxygen of the deprotonated isomer of HL [16] to the empty $3 \mathrm{~d}\left(\mathrm{~d}_{\pi}\right.$ orbitals) of the vanadium ion (Fig. 1) [17].

The infrared spectral analysis of the studied complexes is presented in Table 2. HL exhibited significant bands diagnostic characteristic of the broad vibrations of the two $\mathrm{N}-\mathrm{H}$ bonds $\left(\bar{v}_{\mathrm{N}-\mathrm{H}}\right)$ at $3224 \mathrm{~cm}^{-1}$. This band is associated with that

Table 2 Structural significant infrared spectral assignments $(\bar{v}$, $\mathrm{cm}^{-1}$ ) of the VO-complexes and their corresponding ligand

$b r$ broad band, $s$ strong band, $m$ moderate band, $w$ weak band, ar aromatic ring, alph aliphatic chain

\begin{tabular}{llll}
\hline \multirow{2}{*}{ Group } & \multicolumn{2}{l}{ Complex } & \\
\cline { 2 - 4 } & VO(acac)(L) & VO(L) 2 & HL \\
\hline $\mathrm{N}-\mathrm{H}$ & $3259(\mathrm{~m})$ & $3363(\mathrm{br} \mathrm{m})$ & $3224(\mathrm{br} \mathrm{m})$ \\
$\mathrm{C}-\mathrm{H}_{\mathrm{ar}}$ & $3066(\mathrm{w})$ & $3054(\mathrm{w})$ & $3062(\mathrm{w})$ \\
$\mathrm{C}-\mathrm{H}_{\mathrm{alph}}$ & 2916 & & \\
$\mathrm{C}=\mathrm{O}$ & $1699(\mathrm{~s})$ & & $1684(\mathrm{~s})$ \\
$\mathrm{C}-\mathrm{O}$ & $1550(\mathrm{~m})$ & $1481(\mathrm{~m})$ & \\
& 1314 & & \\
$\mathrm{C}=\mathrm{N}_{(\text {py) }}$ & $1602(\mathrm{~s})$ & $1625(\mathrm{~s})$ & $1558(\mathrm{~m})$ \\
& $624(\mathrm{w})$ & $678(\mathrm{w})$ & $547(\mathrm{~m})$ \\
$\mathrm{C}-\mathrm{N}$ & $1234(\mathrm{w})$ & $1291(\mathrm{~m})$ & $1311(\mathrm{w})$ \\
$\mathrm{C}=\mathrm{N}_{(\text {azomethine })}$ & $1651(\mathrm{~s})$ & $1673(\mathrm{~s})$ & \\
V=O & $987(\mathrm{w})$ & $879(\mathrm{w})$ & \\
V-N & $516(\mathrm{w})$ & $504(\mathrm{w})$ & \\
\hline
\end{tabular}


characteristic band in VO-complexes with little shifted towards the higher frequency (3259 and $3363 \mathrm{~cm}^{-1}$ in $\mathrm{VO}(\mathrm{acac})(\mathrm{L})$ and $\mathrm{VO}(\mathrm{L})_{2}$, respectively). Similarly, the $N$-pyridyl vibrational $\left(\bar{v}_{\text {py }}\right)$ band has a remarkably shifted after the complexation from 1558 and 547 to 1602 and $624 \mathrm{~cm}^{-1}$ in $\mathrm{VO}(\mathrm{acac})(\mathrm{L})$ and to 1625 and $678 \mathrm{~cm}^{-1}$ in $\mathrm{VO}(\mathrm{L})_{2}$, respectively [11]. These corresponded shifts suggest coordination of the oxygen atom of the azomethine group of HL and the nitrogen atom of the $N$-pyridine ring to the $\mathrm{VO}^{2+}$ ion (Table 2). The carbonyl group was confirmed by presence of strong sharp bands at 1684 for $\mathrm{HL}$ and at $1699 \mathrm{~cm}^{-1}$ for $\mathrm{VO}(\mathrm{acac})(\mathrm{L})$, respectively. The $\mathrm{C}=\mathrm{O}$ in $\mathrm{VO}(\mathrm{acac})(\mathrm{L})$ is corresponded to the coordinated acetylacetonate anion. On the other hand, the disappeared stretching vibrational band of $\mathrm{C}=\mathrm{O}$ of the coordinated $\mathrm{HL}$ in $\mathrm{VO}(\mathrm{L})_{2}$ is due to the coordination of the O-atom of the carbonyl group with appearance of a new band at $1673 \mathrm{~cm}^{-1}$ characteristic for the azomethine group $(\mathrm{C}=\mathrm{N})$. The same behavior was noticed took place in coordination of $\mathrm{HL}$ to $\mathrm{VO}^{2+}$ ion in $\mathrm{VO}(\mathrm{acac})(\mathrm{L})$ with appearance of a new band at $1651 \mathrm{~cm}^{-1}$ [11]. IR spectra exhibit a new band $\bar{v}_{(\mathrm{V}=\mathrm{O})}$ at 987 or $879 \mathrm{~cm}^{-1}$ due to the presence of the $\mathrm{V}=\mathrm{O}$ group and another new band $\bar{v}_{(\mathrm{V}-\mathrm{N})}$ at 516 or $504 \mathrm{~cm}^{-1}$ in $\mathrm{VO}(\mathrm{acac})(\mathrm{L})$ and $\mathrm{VO}(\mathrm{L})_{2}$, respectively (Scheme 1). Those stretching vibrational frequencies are well matched with the previously reported values of other oxido-vanadium(IV) complexes $[2,17]$. The remarked difference between the two $\bar{v}_{(\mathrm{V}=\mathrm{O})}$ bands is probably due to the difference electron density or electronic nature of the two coordinated ligands (acac and $\mathrm{HL}$ ) in $\mathrm{VO}(\mathrm{acac})(\mathrm{L})$ and $\mathrm{VO}(\mathrm{L})_{2}$. The high electron-withdrawing ligand (HL) reduces stretching vibrational band of $\mathrm{V}=\mathrm{O}$ in $\mathrm{VO}(\mathrm{L})_{2}$ much more that in $\mathrm{VO}(\mathrm{acac})(\mathrm{L})$. This phenomenon could be observed also in the $\bar{v}_{(\mathrm{V}-\mathrm{N})}$ bands.

The conductivity measurements carried out in DMSO and DMF for $\mathrm{VO}(\mathrm{acac})(\mathrm{L})$ and $\mathrm{VO}(\mathrm{L})_{2}$ at $[$ complex $]=1 \times 10^{-4} \mathrm{~mol} \mathrm{dm}^{-3}$ and $25^{\circ} \mathrm{C}$ awarding very low conducting magnitudes as gathered in Table 3 . The results demonstrate that $\mathrm{VO}(\mathrm{acac})(\mathrm{L})$ and $\mathrm{VO}(\mathrm{L})_{2}$ have non-electrolytic characters. Hence, the general formula of $\mathrm{VO}(\mathrm{acac})(\mathrm{L})$ and $\mathrm{VO}(\mathrm{L})_{2}$ were suggested that acetylacetonate (acac) and 1,3-dipyridin-2-yl-urea (HL) ligands act as monobasic bidentate ligands to form non-electrolytic complexes, as shown in Scheme 1.

Magnetic susceptibility measurements of $\mathrm{VO}(\mathrm{acac})(\mathrm{L})$ and $\mathrm{VO}(\mathrm{L})_{2}$, are measured and presented in Table 3. The results showed that, both $\mathrm{VO}(\mathrm{acac})(\mathrm{L})$ and $\mathrm{VO}(\mathrm{L})_{2}$ as

Table 3 Characteristic magnetic moments $(\mu)$ and molar conductivity measurements $\left(\Lambda_{\mathrm{m}}\right)$ of the VOcomplexes (concentration in electrolytic solution $=1.0 \times 10^{-4} \mathrm{~mol} \mathrm{dm}^{-3}$ ) in DMSO and DMF at $25{ }^{\circ} \mathrm{C}$

\begin{tabular}{|c|c|c|c|c|c|}
\hline \multirow[t]{2}{*}{ Complex } & \multirow[t]{2}{*}{$\begin{array}{l}\mu \\
\text { (B.M.) }\end{array}$} & \multicolumn{2}{|c|}{$\begin{array}{l}\Lambda_{\mathrm{m}} \\
\left(\Omega^{-1} \mathrm{~cm}^{2} \mathrm{~mol}^{-1}\right)\end{array}$} & \multicolumn{2}{|l|}{ ESI-MS $(m / z)$} \\
\hline & & DMSO & DMF & {$[\mathrm{ML}+1]$} & {$[\mathrm{L}-\mathrm{M}+1]$} \\
\hline $\mathrm{VO}(\operatorname{acac})(\mathrm{L})$ & 1.96 & 1.69 & 45 & $380.1,382.9$ & 215.3 \\
\hline $\mathrm{VO}(\mathrm{L})_{2}$ & 2.24 & 1.52 & 32 & $494.2,495.0$ & 215.2 \\
\hline
\end{tabular}

Mass spectral data of VO-complexes (electrospray ionization mass spectra) (in DMSO) 
binary and ternary complexes with highly spin and para-magnetic in a square pyramidal geometrical structures gave 1.24 and 1.76 B.M. values, respectively [18]. Therefore, based on these results and other previously reported literature [11], two points might be concluded: firstly, the vanadium ions in the VO-complexes have no ability for interaction. Secondly, the VO-complexes with the square pyramidal structures are closed system which greatly affects their solubility behavior. The molecular ion $(\mathrm{M}+1)$ peak of all VO-complexes is shown in Figs. S1 and S2 (Supplementary Information). The relevant results confirmed that obtained and expected values of mass spectra matched appreciably indicating the mononuclearity of the VO-complexes without any interaction between $\mathrm{VO}^{2+}$ ions.

\section{Determination of thermodynamic parameters of the oxovanadium complexes}

The stoichiometry of the VO-complexes was estimated particularly by spectrophotometric continuous variation methods [19]. The spectral data confirm that the molar ratios of metal, $\mathrm{VO}^{2+}$, to ligand $(\mathrm{HL})$ in $\mathrm{VO}(\mathrm{L})_{2}$ is $1: 2$, and is $1: 1$ in $\mathrm{VO}(\mathrm{acac})(\mathrm{L})$ as documented in Fig. S3 (Supplementary Information). The formation constants $K_{f}$ of $\mathrm{VO}(\mathrm{acac})(\mathrm{L})$ and $\mathrm{VO}(\mathrm{L})_{2}$, are calculated by using Eq. 1 which derived from the continuous variation method:

$$
K_{f}=\frac{A / A_{x}}{\left(1-A / A_{x}\right)^{2} C}
$$

where $A_{x}$ is the absorbance at the complete formation of the VO-complex according to the continuous variation plot (Fig. S3), $A$ is the absorbance of the complex at the despotic recognized concentration $C$ of metal ion, $\mathrm{VO}^{2+}$. The calculated values

Table 4 Stability constants and thermodynamic parameters of the VO-complexes, [VO-complex $]=1.0 \times 10^{-5} \mathrm{~mol} \mathrm{dm}^{-3}$

\begin{tabular}{lcllll}
\hline Complex & $\mathrm{T}\left({ }^{\circ} \mathrm{C}\right)$ & $K_{f} \times 10^{6}$ & $\begin{array}{l}-\Delta_{f} \mathrm{G} \\
\left(\mathrm{kJ} \mathrm{mol}^{-1}\right)\end{array}$ & $\begin{array}{l}-\Delta_{f} \mathrm{H} \\
\left(\mathrm{kJ} \mathrm{mol}^{-1}\right)\end{array}$ & $-\Delta_{f} \mathrm{~S}\left(\mathrm{~J} \mathrm{~mol}^{-1} \mathrm{~K}^{-1}\right)$ \\
\hline $\mathrm{VO}(\mathrm{acac})(\mathrm{L})$ & 20 & $\begin{array}{c}4.77 \\
\left(\mathrm{~L} \mathrm{~mol}^{-1}\right)\end{array}$ & 54.28 & 4.22 & 7.91 \\
& 25 & 4.23 & 54.91 & & \\
& 30 & 3.29 & 55.42 & & \\
& 35 & 2.51 & 55.88 & & \\
& 40 & 1.95 & 56.43 & & \\
$\mathrm{VO}(\mathrm{L})_{2}$ & 20 & 5.37 & 54.57 & & \\
& & $\left(\mathrm{~L} \mathrm{~mol}{ }^{-1}\right)$ & & & \\
& 25 & 4.75 & 55.20 & & \\
& 30 & 3.92 & 55.66 & & \\
& 35 & 3.46 & 56.23 & & \\
& 40 & 2.84 & 56.64 & & \\
\hline
\end{tabular}


(Table 4), showed that, all the prepared complexes exhibited high thermal stability characters [11].

The $K_{f}$ values for the studied complexes considerably reflect the decrease of substitution reaction of $\mathrm{HL}$ with one of acetylacetonate ion (acac) in $\mathrm{VO}(\mathrm{acac})(\mathrm{L})$ or with two ions of ac in $\mathrm{VO}(\mathrm{L})_{2}$. The $K_{f}$ values in Table 4 indicating that $\mathrm{VO}(\mathrm{L})_{2}$ is more stable than $\mathrm{VO}(\mathrm{acac})(\mathrm{L})$.

The thermodynamic parameters of the VO-complexes formation could be calculated from the determined equilibrium formation constant at different temperatures. The Gibbs-Helmholtz equation, via using Eq. 2, which could be applied to determine $\Delta_{f} \mathrm{H}$ and $\Delta_{f} \mathrm{~S}$ from the slope and intercept, respectively, of the linear plotting relationship of $\ln K_{f}$ values as function of 1/T (Fig. 2). The calculated thermodynamic parameters are gathered in Table 4.

$$
\frac{\Delta_{f} G}{T}=-R \ln K_{f}
$$

The negative values of $\Delta_{f} G$ reflect that, the formation of the current VOcomplexes under all the studied conditions is spontaneous process. As $\Delta_{f} \mathrm{H}$ is positive, this refers to, the complex formation was endothermic reaction, and the metal-ligand bonds are much stronger, especially for $\mathrm{VO}(\mathrm{L})_{2}$ [11]. Therefore, from the thermodynamic point of view and, the thermodynamic data indicating that, $\mathrm{VO}(\operatorname{acac})(\mathrm{L})$ is more reactive than $\mathrm{VO}(\mathrm{L})_{2}$ (Fig. 3).

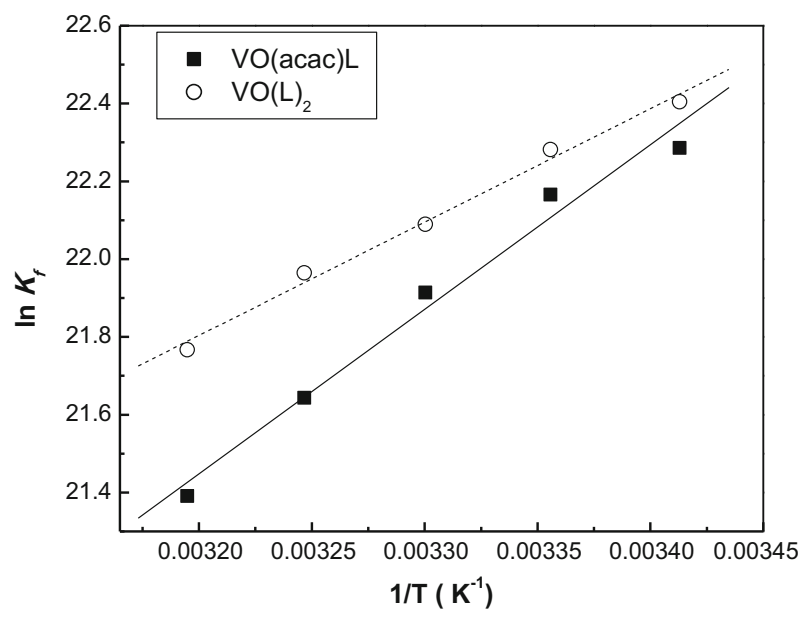

Fig. 2 Determination of thermodynamic parameters of $\mathrm{VO}(\mathrm{acac})(\mathrm{L})$ and $\mathrm{VO}(\mathrm{L})_{2}$ formation from $\ln K_{f}$ values 

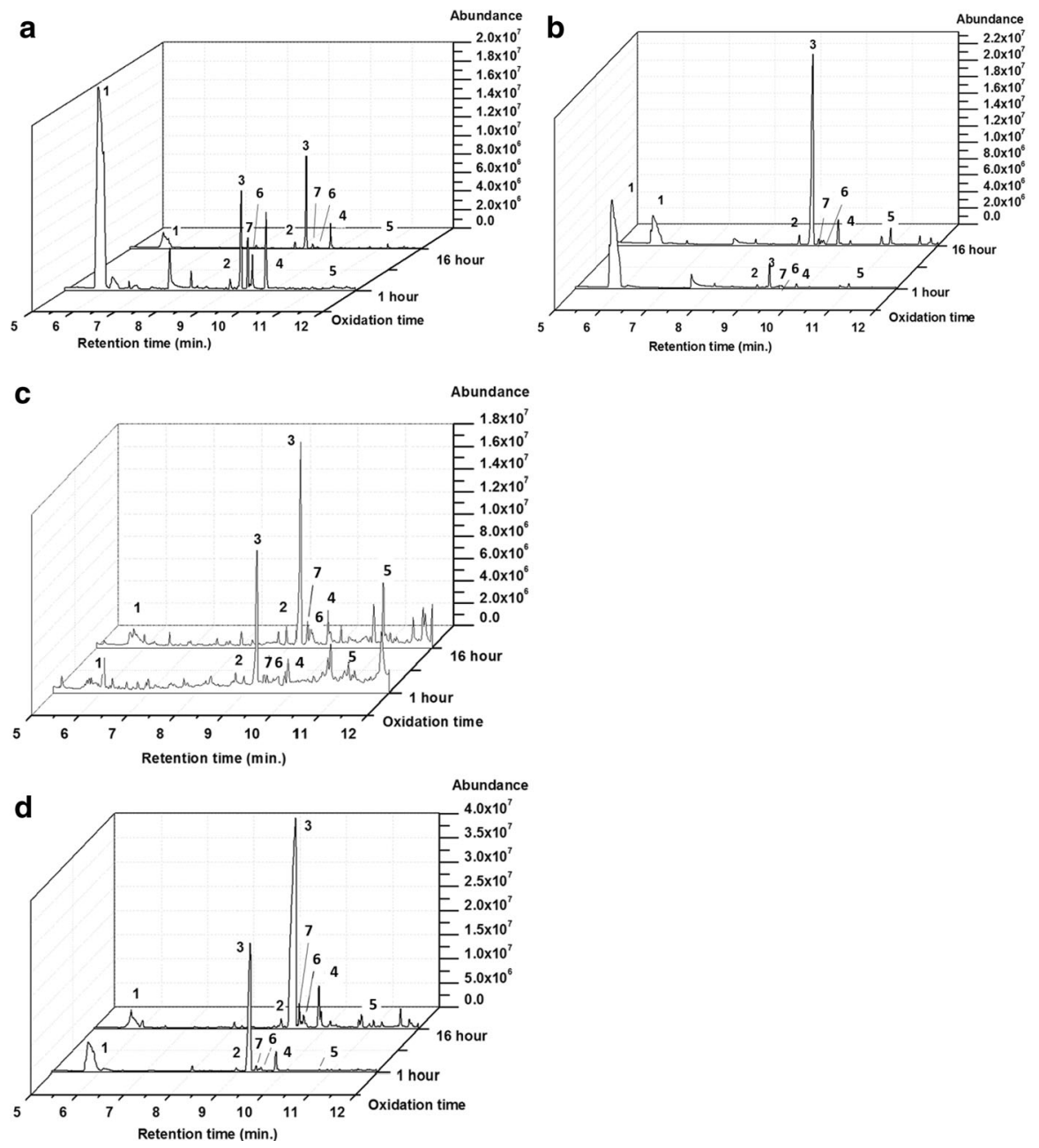

Fig. 3 The catalytic (ep)oxidation of cis-cyclooctene chromatogram using different oxidation time (1 and 16 h) by $\mathrm{VO}(\mathrm{L})_{2}$ using an aqueous $\mathrm{H}_{2} \mathrm{O}_{2}\left(\right.$ a), TBHP (b) or by $\mathrm{VO}\left(\right.$ acac)(L) using an aqueous $\mathrm{H}_{2} \mathrm{O}_{2}$ (c), TBHP (d) at $85^{\circ} \mathrm{C}$

\section{Catalytic studies}

\section{Catalytic (ep)oxidation of cis-cyclooctene and 1-octene}

Mononuclear oxo-vanadium complexes are well known catalysts for various oxidation processes with moderate to high selectivity. Oxovanadium complexes are high effective catalysts for (ep)oxidation of alkenes [20], specifically ciscyclooctene and 1-octene by an aqueous $\mathrm{H}_{2} \mathrm{O}_{2}$ or TBHP in various reaction conditions [5, 21, 22]. Particularly, the chemoselective and target product of ciscyclooctene (ep)oxidation is epoxy-1,2-cyclooctane in high scale with 
contamination of other side products. Epoxy-1,2-octane is the target product of the 1-octene (ep)oxidation, which is also contaminated with other unwanted products. To the best of our knowledge, it is so far in literatures to explore all possible catalytic (ep)oxidation products of cis-cyclooctene [23] and 1-octene [11] qualitatively and quantitatively. So, the most advantage here is to report the ratios of the most possible products of the cis-cyclooctene or 1-octene (ep)oxidation using an aqueous $\mathrm{H}_{2} \mathrm{O}_{2}$ or TBHP catalyzed by $\mathrm{VO}($ acac $)(\mathrm{L})$ or $\mathrm{VO}(\mathrm{L})_{2}$ in various reaction conditions. Consequently, all possible molecular structure of the (ep)oxidation products of cis-cyclooctene and 1-octene, as representative unsaturated alkanes, using either an aqueous $\mathrm{H}_{2} \mathrm{O}_{2}$ or TBHP catalyzed by $\mathrm{VO}(\mathrm{acac})(\mathrm{L})$ or $\mathrm{VO}(\mathrm{L})_{2}$ at various reaction conditions are considerably identified and determined qualitatively and quantitatively by GC-MS. They are summarized and presented in Tables 5, 6 and 7. There was no observable conversion of cis-cyclooctene or 1,2-octene in absence of the current VO-complex catalysts.

The conversion and chemoselectivity of the alkene (ep)oxidation to the epoxyproduct mainly depends on, the type of catalyst, type of oxidant, and the reaction conditions from solvents and temperature [8, 10]. Therefore, there are five unexpected side products have been identified for the (ep)oxidation of ciscyclooctene namely: 4-cyclooctene-1-one (2), 2-cyclooctene-1-one (4), 2-hydroxycyclooctanone (5), cyclooctane-1,2-diol (6), and cyclooctanone (7) (Scheme 2, Tables 5 and 6) [24]. However, another 5 side products have been identified for (ep)oxidation of 1-octene namely: 7-octen-2-one $\left(\mathbf{2}^{\prime}\right), 2$-octenal $\left(\mathbf{4}^{\prime}\right), 1$-octanoic acid $\left(\mathbf{5}^{\prime}\right)$, 1,2-octanediol $\left(\mathbf{6}^{\prime}\right)$ and octanal $\left(\mathbf{7}^{\prime}\right)$ (Scheme 3, Table 7). Some of those products are unexpected and not reported elsewhere. The conversion and chemoselectivity depend upon the ratio epoxy product in the catalytic process [8], they proceeded by the type of catalysts, type of oxidant and the catalytic reaction conditions [10].

By definition of the other formed side products at the end of each catalytic process at 45,70 or $85^{\circ} \mathrm{C}$ (Table 5), it is highly notable that the formed epoxide 3 experienced further oxidation to give $\mathbf{5}$, which underwent nucleophilic ring opening of 3 with aqueous hydrolysis forming 6 and 7 (Fig. 4) [23]. From Scheme 2, the amount of $\mathbf{5}$ and $\mathbf{6}$ depends upon the type of oxidant. Using an aqueous $\mathrm{H}_{2} \mathrm{O}_{2}$, ratios of $\mathbf{5}$ and $\mathbf{6}$ are high, while with TBHP, their amount ratios were reduced remarkably (Tables 5,6). The presence of water with the molecular $\mathrm{H}_{2} \mathrm{O}_{2}$ could probably causes aqueous hydrolysis and so improves the production of both 2-hydroxy-cyclooctanone (5) and cyclooctane-1,2-diol (6) (nucleophilic ring opening reaction) in the catalytic process compared to that process with TBHP $[25,26]$. This suggestion could be acceptable due to the absence of any amount of $\mathbf{5}$ as a side product using TBHP after $16 \mathrm{~h}$ at $45{ }^{\circ} \mathrm{C}$ (Table 6). GC-MS analyses detected two unexpected (ep)oxidation products which are 4-cyclooctene-1-one (2) and 2-cyclooctene-1-one (4). Carbon atoms $\mathrm{C}-3$ or/and -8 and $\mathrm{C}-5$ or/and -6 to the $\mathrm{C}=\mathrm{C}$ group in ciscyclooctene molecule are high reactive to be incorporated in the oxidation reaction by either $\mathrm{H}_{2} \mathrm{O}_{2}$ or TBHP with observable amounts of $\mathbf{2}$ and $\mathbf{4}$ especially at high temperature $\left(85^{\circ} \mathrm{C}\right.$ ) catalyzed by $\mathrm{VO}(\mathrm{acac})(\mathrm{L})$ or $\mathrm{VO}(\mathrm{L})_{2}$ (Table 5). Such work is similarly reported for the oxidation of cyclohexene previously by Maurya et al. [27] and Lashanizadegan et al. [28]. 


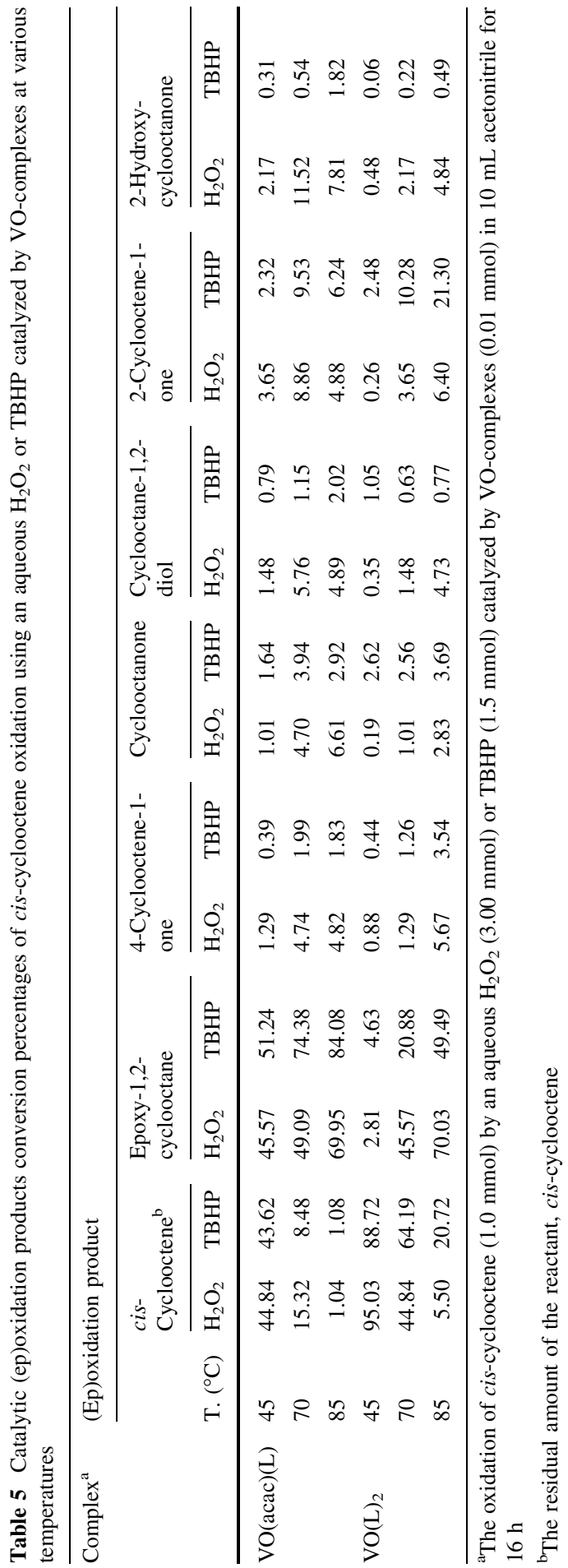




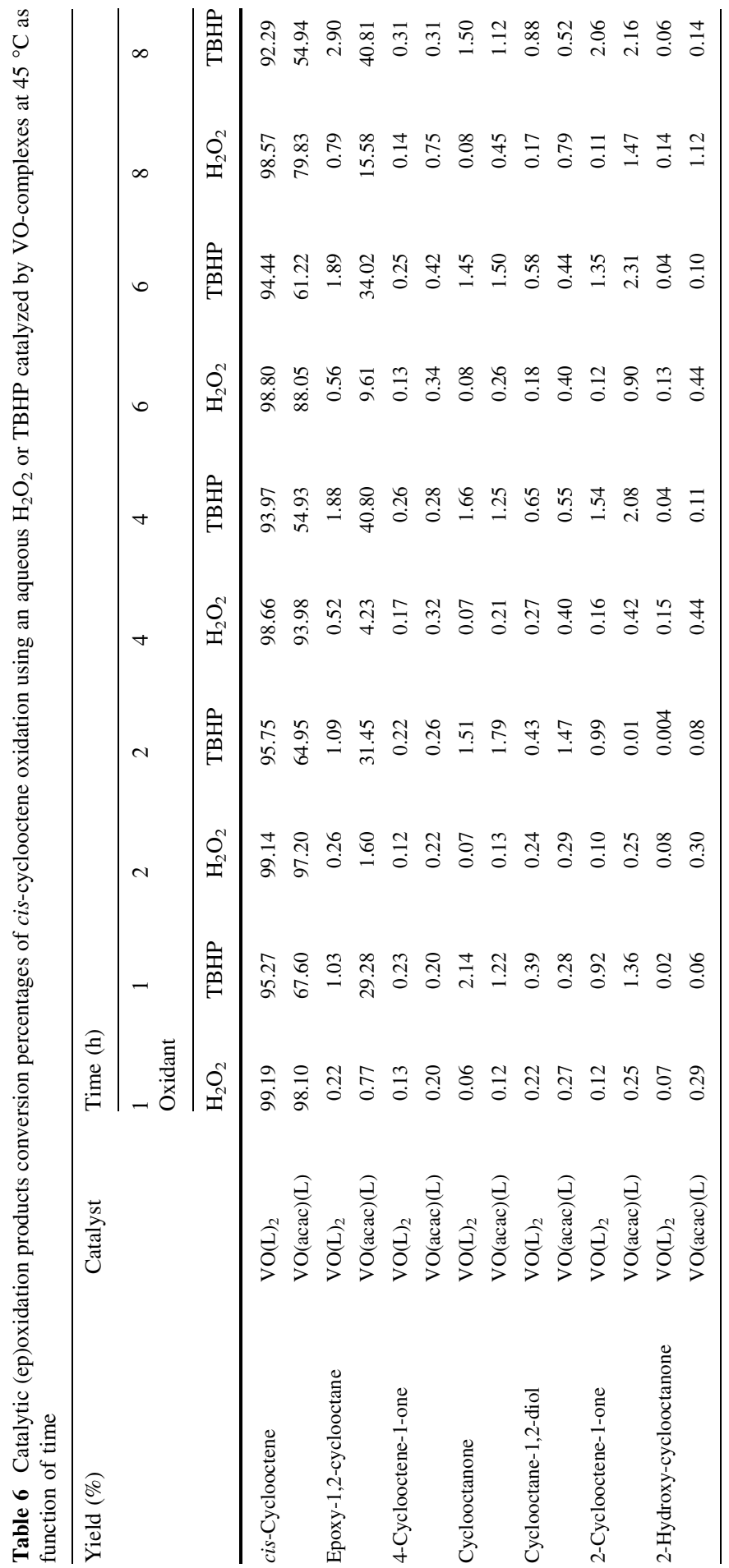

\section{Springer}




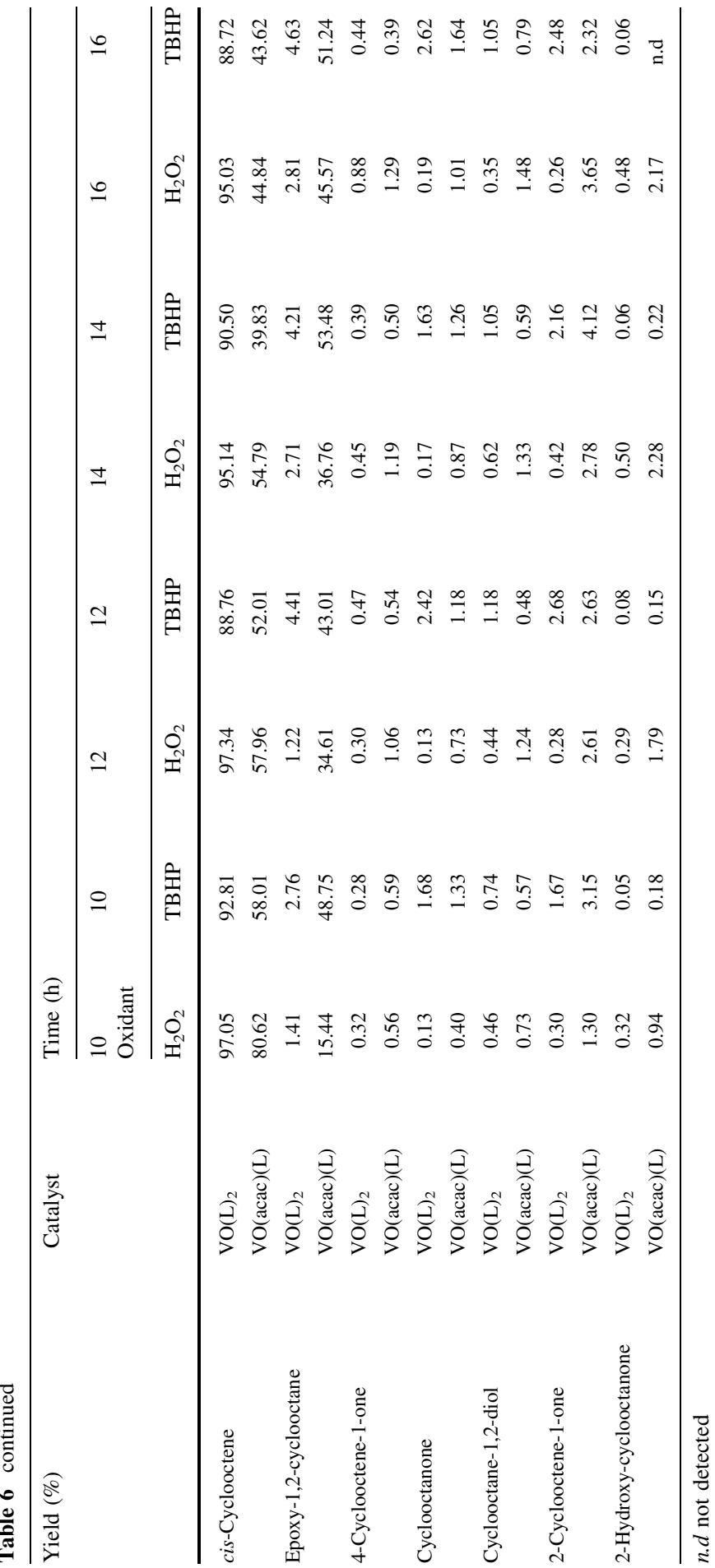




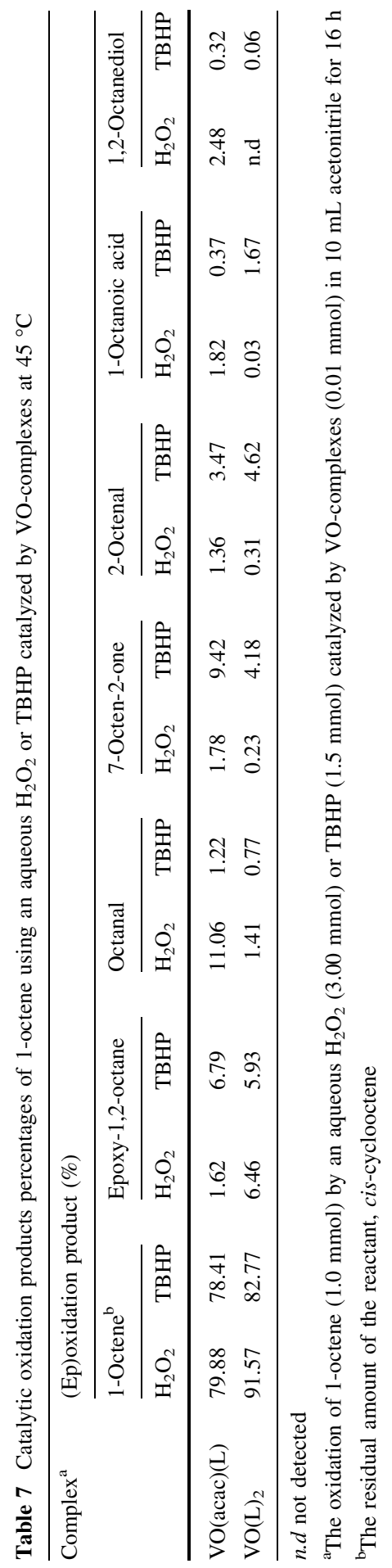




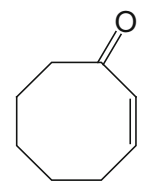

2-cyclooctene-1-one

4

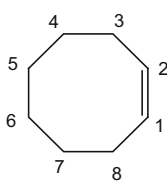

1

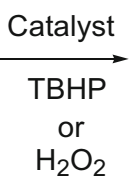

or
$\mathrm{H}_{2} \mathrm{O}_{2}$

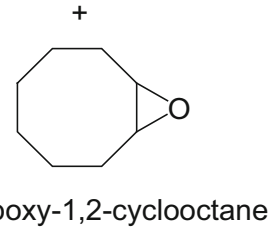

3

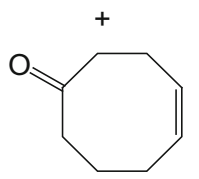

4-cyclooctene-1-one

2

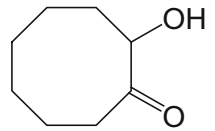

2-hydroxy-cyclooctanone<smiles>OC1CCCCCCC1O</smiles>

cyclooctane-1,2-diol

6

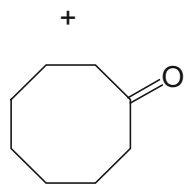

cyclooctanone

7

Scheme 2 Products of the catalytic (ep)oxidation of cis-cyclooctene using either an aqueous $\mathrm{H}_{2} \mathrm{O}_{2}$ or TBHP catalyzed by $\mathrm{VO}(\mathrm{acac})(\mathrm{L})$ or $\mathrm{VO}(\mathrm{L})_{2}$ in acetonitrile for $16 \mathrm{~h}$ at $85^{\circ} \mathrm{C}$

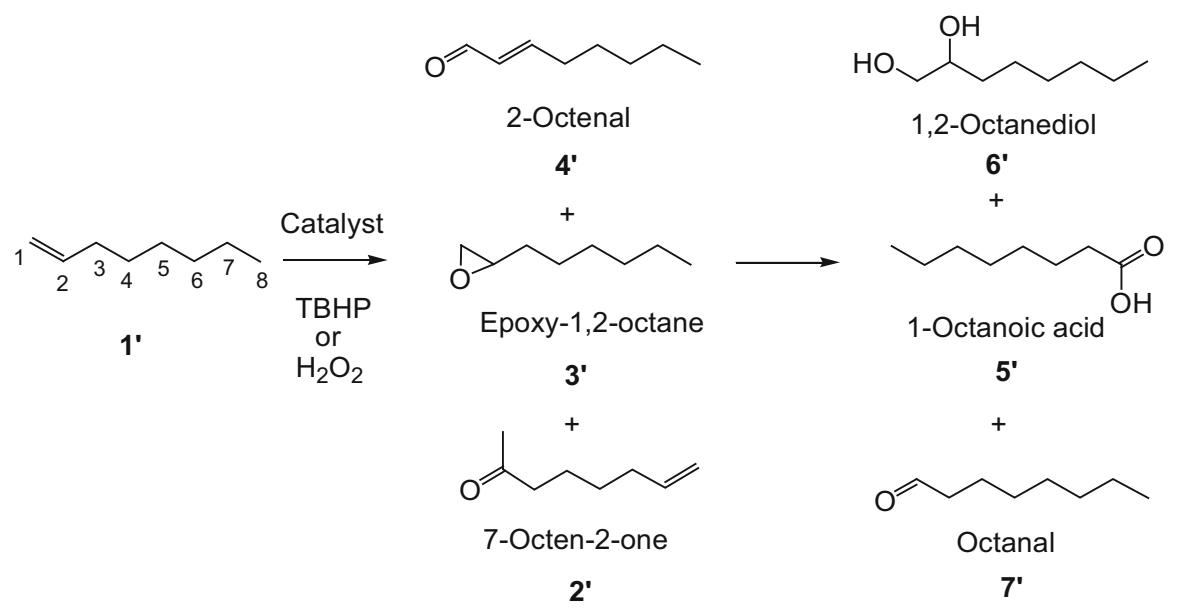

Scheme 3 Products of the catalytic oxidation of 1-octene using either an aqueous $\mathrm{H}_{2} \mathrm{O}_{2}$ or TBHP catalyzed by $\mathrm{VO}(\mathrm{acac})(\mathrm{L})$ or $\mathrm{VO}(\mathrm{L})_{2}$ in acetonitrile for $16 \mathrm{~h}$ at $45^{\circ} \mathrm{C}$ 


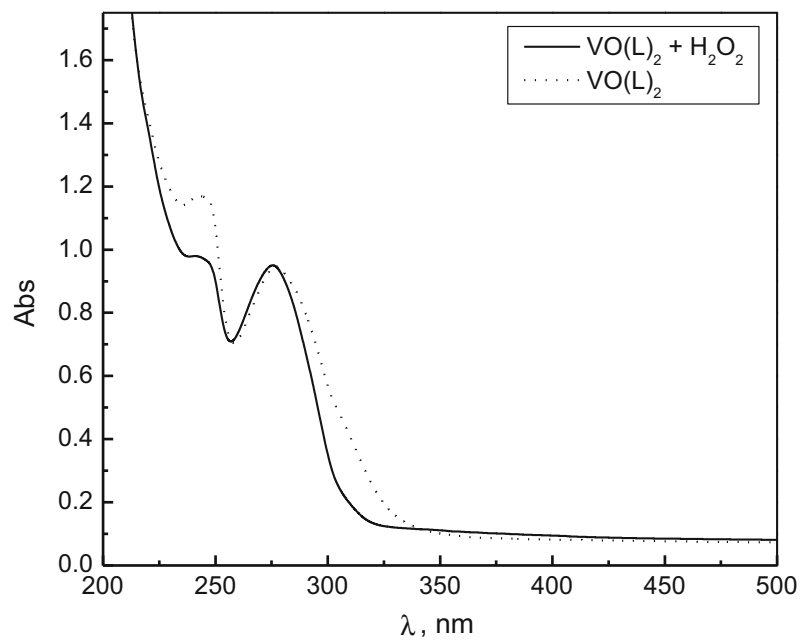

Fig. 4 UV-Visible spectral scan of $\mathrm{VO}(\mathrm{L})_{2}$ in absence and after mixing with an aqueous $\mathrm{H}_{2} \mathrm{O}_{2}$ in acetonitrile at $25^{\circ} \mathrm{C}$, [complex] $=0.01$ and $\left[\mathrm{H}_{2} \mathrm{O}_{2}\right]=3.0 \mathrm{~mol} \mathrm{dm}^{-3}$ (with dilution 2 times)

The catalytic (ep)oxidation of 1-octene is quite reactive with low regio- and chemoselecitivity compared to that redox process of cis-cyclooctene [5, 29, 30]. $\mathrm{VO}($ acac $)(\mathrm{L})$ and $\mathrm{VO}(\mathrm{L})_{2}$ have high catalytic potential for the (ep)oxidation of 1-octene using either an aqueous $\mathrm{H}_{2} \mathrm{O}_{2}$ or TBHP, in acetonitrile at low temperature $\left(45^{\circ} \mathrm{C}\right)$ after $16 \mathrm{~h}$. The catalytic process products are shown in Scheme 3 and are listed with various ratios in Table 7 . However, $\mathrm{VO}(\mathrm{acac})(\mathrm{L})$ and $\mathrm{VO}(\mathrm{L})_{2}$ show high quite high regio- and chemoselectivity for the (ep)oxidation of cis-cyclooctene, they have low regio- and chemoselective control for the same process of 1-octene. These results agree with the obtained previously by us of VO-complexes of 1,3-dipyridin2-yl-thiourea and cumarin [11]. The further oxidation of $\mathbf{3}^{\prime}$ is similar to that of $\mathbf{3}$ to give 5 which involved for further nucleophilic ring opening to afford $\mathbf{5}^{\prime}$, which followed by aqueous hydrolysis of $\mathbf{5}^{\prime}$ to give $\mathbf{6}^{\prime}$ and $\mathbf{7}^{\prime}$ (Scheme 3 ).

Effect of various reaction parameters, e.g. temperatures $\left(45,70\right.$ and $\left.85{ }^{\circ} \mathrm{C}\right)$, type/ ratio of catalyst $\left(\mathrm{VO}(\mathrm{acac})(\mathrm{L})\right.$ or $\left.\mathrm{VO}(\mathrm{L})_{2}\right)$, solvent and type of oxidant (an aqueous $\mathrm{H}_{2} \mathrm{O}_{2}$ or TBHP) were studied to obtain the optimized (ep)oxidation reaction conditions of cis-cyclooctene in order to realize the highest amount of the target product, i.e. epoxy-product. Tables 5 and 6 show that $\mathrm{VO}(\mathrm{acac})(\mathrm{L})$ and $\mathrm{VO}(\mathrm{L})_{2}$ are effective catalysts and have high control chemoselectivity in the (ep)oxidation process (Scheme 2).

\section{Effect of temperature in the cis-cyclooctene (ep)oxidation reaction}

The catalytic processes initiated by injection of cis-cyclooctene $(1.0 \mathrm{mmol})$ with either of $\mathrm{VO}(\mathrm{acac})(\mathrm{L})$ or $\mathrm{VO}(\mathrm{L})_{2}(0.01 \mathrm{mmol})$, as the catalyst, and an aqueous $\mathrm{H}_{2} \mathrm{O}_{2}$ $(3.0 \mathrm{mmol})$ or TBHP $(1.5 \mathrm{mmol})$, as the oxidant, at different reaction temperatures $\left(45,70\right.$ or $\left.85^{\circ} \mathrm{C}\right)$ in acetonitrile $(10 \mathrm{~mL})$. $\mathrm{VO}(\mathrm{acac})(\mathrm{L})$ and $\mathrm{VO}(\mathrm{L})_{2}$ exhibit 
moderate to excellent catalytic control and chemoselectivity for the conversion of cis-cyclooctene, as shown in Tables 5 and 6.

At low temperature, $45^{\circ} \mathrm{C}$, the conversion and chemoselectivity of ciscyclooctene to epoxy target product catalyzed by either $\mathrm{VO}(\mathrm{acac})(\mathrm{L})$ or $\mathrm{VO}(\mathrm{L})_{2}$ was low even after long time (16 h), as observed in Table 6 . After $16 \mathrm{~h}$, the control chemoselectivity with both catalyst complexes to the target product was moderate at $70{ }^{\circ} \mathrm{C}$ and good at the highest reaction temperature $\left(85^{\circ} \mathrm{C}\right)$ compared to that at $45{ }^{\circ} \mathrm{C}$.

At $70{ }^{\circ} \mathrm{C}$, the conversion was improved remarkably with $\mathrm{VO}(\mathrm{acac})(\mathrm{L})(84.68$ and $91.52 \%$ using either $\mathrm{H}_{2} \mathrm{O}_{2}$ or TBHP, respectively) to afford good percentage of the chemoselective product (49.09 and $74.38 \%$ using either $\mathrm{H}_{2} \mathrm{O}_{2}$ or TBHP, respectively). With $\operatorname{VO}(\mathrm{L})_{2}$, the conversion was excellent (84.68 and $91.52 \%$ using either $\mathrm{H}_{2} \mathrm{O}_{2}$ or TBHP, respectively) with moderate to low amount of chemoselective product depending upon the type of oxidant (45.57 and $20.88 \%$ using either $\mathrm{H}_{2} \mathrm{O}_{2}$ or TBHP, respectively). The highest effective catalytic potentials $\mathrm{VO}(\mathrm{acac})(\mathrm{L})$ and $\mathrm{VO}(\mathrm{L})_{2}$ catalysts could be observed at $85{ }^{\circ} \mathrm{C}$ ( $\sim$ boiling point of acetonitrile $)$ after $16 \mathrm{~h}$. The uncontrol conversion was excellent with $\mathrm{VO}(\mathrm{acac})(\mathrm{L})(98.96$ and $98.92 \%$ using either $\mathrm{H}_{2} \mathrm{O}_{2}$ or TBHP, respectively) and the chemoselectivity was also remarkably excellent to afford epoxy-1,2-cyclooctane (69.95 and $84.08 \%$ using either $\mathrm{H}_{2} \mathrm{O}_{2}$ or TBHP, respectively) (Table 5). On the other hand, the conversion was good to excellent with $\mathrm{VO}(\mathrm{L})_{2}\left(94.50\right.$ and $79.28 \%$ using either $\mathrm{H}_{2} \mathrm{O}_{2}$ or TBHP, respectively) and the chemoselectivity was good (70.03 and $49.49 \%$ using either $\mathrm{H}_{2} \mathrm{O}_{2}$ or TBHP, respectively) (Table 5).

In particular, the effect of temperature is high effective parameter for determination of the optimized catalytic reaction condition of the (ep)oxidation of cis-cyclooctene using either an aqueous $\mathrm{H}_{2} \mathrm{O}_{2}$ or TBHP catalyzed by $\mathrm{VO}(\mathrm{acac})(\mathrm{L})$ or $\mathrm{VO}(\mathrm{L})_{2}$ (Fig. 3). So, the optimized reaction temperature for the (ep)oxidation of cis-cyclooctene catalyzed by either $\mathrm{VO}(\mathrm{acac})(\mathrm{L})$ or $\mathrm{VO}(\mathrm{L})_{2}$ using an aqueous $\mathrm{H}_{2} \mathrm{O}_{2}$ or TBHP is $85^{\circ} \mathrm{C}$ for $16 \mathrm{~h}$. It could be observed from the chromatograph that the intensities of cis-cyclooctene peaks are dramatically decreased, while the intensities of epoxy, 1,2-cyclooctene peaks are increased by prolongation of the oxidation time from 1 to $16 \mathrm{~h}$. These observations are true for the (ep)oxidation of cis-cyclooctene catalyzed by either $\mathrm{VO}(\mathrm{acac})(\mathrm{L})$ using an aqueous $\mathrm{H}_{2} \mathrm{O}_{2}$ (Fig. 3a) and TBHP (Fig. 3b), or $\mathrm{VO}(\mathrm{L})_{2}$ using an aqueous $\mathrm{H}_{2} \mathrm{O}_{2}$ (Fig. 3c) and TBHP (Fig. 3d).

The percentages of the other side products, as listed in Table 5, are low in both $\mathrm{VO}(\mathrm{acac})(\mathrm{L})$ and $\mathrm{VO}(\mathrm{L})_{2}, 29.01$ or $24.47 \%$ using $\mathrm{H}_{2} \mathrm{O}_{2}$ and 14.84 or $29.79 \%$, using TBHP, respectively. The ratios of the side products are also depending upon the reaction temperatures which increased by increasing the temperature.

In significant, the catalytic process could be performed by increasing the reaction temperature depending upon the catalyst solubility and hydrolytic stability which resulted from the thermodynamic parameters (Table 4, Fig. 2). The solubility and hydrolytic stability of the VO-catalysts could be an effective parameter in the performance of the catalytic process [20]. At low temperature $\left(45^{\circ} \mathrm{C}\right)$, $\mathrm{VO}(\mathrm{acac})(\mathrm{L})$ or $\mathrm{VO}(\mathrm{L})_{2}$ have low catalytic potential using an aqueous $\mathrm{H}_{2} \mathrm{O}_{2}$ or TBHP. This could refer to the heterogeneous nature and less reactivity of the 
catalyst, as observed experimentally and in previous studies for $\mathrm{Mo}^{\mathrm{IV}} \mathrm{O}_{2}$-dihydrazone catalysts [31]. At high temperature $\left(85^{\circ} \mathrm{C}\right)$, both VO-complexes are highly dissolved and more hydrolytic reactive in the reaction media and so both exhibit high catalytic activity for the (ep)oxidation of cis-cyclooctene, homogeneously. Conclusively, the optimized catalytic conditions are obtained at $85{ }^{\circ} \mathrm{C}$ after $16 \mathrm{~h}$ with $0.01 \mathrm{mmol}$ of $\mathrm{VO}(\mathrm{acac})(\mathrm{L})$ and $\mathrm{VO}(\mathrm{L})_{2}$.

\section{Effect of type of catalysts and catalyst/substrate ratios}

Table 8 shows the effect of the catalyst amount ratio to the substrate $(0.01: 1,0.05: 1$ and $0.10: 1$ ) in the proceeding of the catalytic (ep)oxidation. It is observed that the increase of the catalyst ratio reduces the (ep)oxidation time of cis-cyclooctene at $85{ }^{\circ} \mathrm{C}$ from $16 \mathrm{~h}$ (optimum reaction conditions) using $0.01 \mathrm{mmol}$ to $4 \mathrm{~h}$ using $0.05 \mathrm{mmol}$ and to $\sim 1.5 \mathrm{~h}$ using $0.1 \mathrm{mmol}$ of either $\mathrm{VO}(\mathrm{acac})(\mathrm{L})$ or $\mathrm{VO}(\mathrm{L})_{2}$ with remarkable improvement in the amount of the chemoselective product.

The electronic and steric effects [32-34] of the coordinated ligands and their substituents to $\mathrm{VO}^{2+}$ ion have subtle influence on the catalytic potential of the VOcomplex catalyst [8]. It seems that the coordinated ligands acac or HL has a remarkable effect on the catalytic potential of $\mathrm{VO}(\mathrm{acac})(\mathrm{L})$ and $\mathrm{VO}(\mathrm{L})_{2}$, sterically and electronically, as observed in previous work by our group [21]. Both effects could be remarked in the electrophilic character of the central $\mathrm{VO}^{2+}$ ion by the attach of the nucleophiles, i.e. $\mathrm{H}_{2} \mathrm{O}_{2}$ or TBHP to the central metal ion [30], especially after formation of the active $\mathrm{VO}^{+}$intermediate (I) see the mechanistic pathway.

Table 8 Catalytic (ep)oxidation products conversion percentages of cis-cyclooctene oxidation using an aqueous $\mathrm{H}_{2} \mathrm{O}_{2}$ or TBHP catalyzed by VO-complexes at $85{ }^{\circ} \mathrm{C}$ for with different amounts of VO-catalyst

\begin{tabular}{|c|c|c|c|c|c|c|c|c|}
\hline \multirow[t]{3}{*}{ Complex $^{a}$} & \multicolumn{8}{|l|}{ (Ep)oxidation product $(\%)$} \\
\hline & \multirow[t]{2}{*}{ Catalyst amount, mmol } & \multirow[t]{2}{*}{ Time (h) } & \multicolumn{2}{|c|}{$\begin{array}{l}\text { Cis- } \\
\text { cyclooctene }\end{array}$} & \multicolumn{2}{|c|}{$\begin{array}{l}\text { Epoxy-1,2- } \\
\text { cyclooctane }\end{array}$} & \multicolumn{2}{|c|}{$\begin{array}{l}\text { Other } \\
\text { products }\end{array}$} \\
\hline & & & $\mathrm{H}_{2} \mathrm{O}_{2}$ & TBHP & $\mathrm{H}_{2} \mathrm{O}_{2}$ & TBHP & $\mathrm{H}_{2} \mathrm{O}_{2}$ & TBHP \\
\hline \multirow[t]{3}{*}{$\mathrm{VO}(\mathrm{acac})(\mathrm{L})$} & 0.01 & 16 & 1 & 1 & 70 & 84 & 29 & 15 \\
\hline & 0.05 & 4 & 2 & 3 & 75 & 86 & 23 & 11 \\
\hline & 0.1 & 1 & 1 & 0 & 81 & 86 & 18 & 14 \\
\hline \multirow[t]{3}{*}{$\mathrm{VO}(\mathrm{L})_{2}$} & 0.01 & 16 & 6 & 21 & 70 & 50 & 19 & 29 \\
\hline & 0.05 & 4 & 3 & 9 & 74 & 65 & 22 & 26 \\
\hline & 0.1 & 1.5 & 0 & 4 & 77 & 74 & 23 & 22 \\
\hline
\end{tabular}

${ }^{\text {a }}$ The oxidation of cis-cyclooctene $(1.0 \mathrm{mmol})$ by an aqueous $\mathrm{H}_{2} \mathrm{O}_{2}(3.00 \mathrm{mmol})$ or TBHP $(1.5 \mathrm{mmol})$ catalyzed by VO-complexes $(0.01 \mathrm{mmol})$ in $10 \mathrm{~mL}$ acetonitrile

${ }^{\mathrm{b}}$ The residual amount of the reactant

${ }^{\mathrm{c}}$ The other side products are listed as in Tables 5 and 6 
Electronically, however, the coordination of $\mathrm{VO}^{2+}$ ion to one HL ligand through $\mathrm{N}$ - and $\mathrm{O}$-atoms and with two O-atoms of acetylacetonate anion (acac), in $\mathrm{VO}(\mathrm{acac})(\mathrm{L})$ could probably form more reactive due to the high reactivity of the acetylacetonate group (acac), than its chelating to the two $\mathrm{HL}$ ligands, $\mathrm{VO}(\mathrm{L})_{2}$, as observed for vanadyl complexes by Rayati et al. [32] and by Maurya et al. [33]. Sterically, the more steric ligands decrease the catalytic activity of the catalyst [8], hence, the steric effect is remarked in $\mathrm{VO}(\mathrm{L})_{2}$ compared to $\mathrm{VO}(\mathrm{acac})(\mathrm{L})$. Consequently, $\mathrm{VO}(\mathrm{acac})(\mathrm{L})$ is more reactive and sufficient catalyst than $\mathrm{VO}(\mathrm{L})_{2}$ in such redox process, Table 8 . This also could be elucidated by the thermodynamic parameters and formation constants (Table 4 and Fig. 2), $\mathrm{VO}(\mathrm{L})_{2}$ is little less stable than $\mathrm{VO}(\mathrm{acac})(\mathrm{L})$. The electronic and steric effects [32-34] could be remarked in the catalytic potentials of the VO-complexes by the electron transfer to the central metal ion and the oxygen transfer step in the catalytic processes (mechanistic pathway [30]).

\section{Effect of solvents and type of oxidants}

The catalytic potential of oxovanadium complexes has been remarkably influenced by the nature of the solvent on (ep)oxidation processes, as reported recently [35-38]. The effect of different organic solvents in nature, i.e. acetone, dichloromethane, chloroform and DMF ( $N, N^{\prime}$-dimethylformamide), on the (ep)oxidation of cis-cyclooctene by either an aqueous $\mathrm{H}_{2} \mathrm{O}_{2}$ or TBHP catalyzed by

Table 9 Catalytic (ep)oxidation products conversion percentages of cis-cyclooctene oxidation using an aqueous $\mathrm{H}_{2} \mathrm{O}_{2}$ or TBHP catalyzed by VO-complexes at $85{ }^{\circ} \mathrm{C}$ for in different solvents

\begin{tabular}{|c|c|c|c|c|c|c|c|}
\hline \multirow[t]{3}{*}{ Complex $^{\mathrm{a}}$} & \multicolumn{7}{|c|}{ (Ep)oxidation product (\%) } \\
\hline & \multirow[t]{2}{*}{ Solvent } & \multicolumn{2}{|c|}{ Cis-cyclooctene ${ }^{\mathrm{b}}$} & \multicolumn{2}{|c|}{ Epoxy-1,2-cyclooctane } & \multicolumn{2}{|c|}{ Other products ${ }^{c}$} \\
\hline & & $\mathrm{H}_{2} \mathrm{O}_{2}$ & TBHP & $\mathrm{H}_{2} \mathrm{O}_{2}$ & TBHP & $\mathrm{H}_{2} \mathrm{O}_{2}$ & TBHP \\
\hline \multirow[t]{5}{*}{$\mathrm{VO}(\mathrm{acac})(\mathrm{L})$} & Acetonitrile & 1 & 1 & 70 & 84 & 29 & 15 \\
\hline & Chloroform & 4 & 2 & 65 & 79 & 31 & 19 \\
\hline & Acetone & 2 & 5 & 40 & 42 & 58 & 53 \\
\hline & DMF & 0 & 8 & 51 & 44 & 49 & 48 \\
\hline & $\mathrm{CCl}_{4}$ & 6 & 0 & 58 & 87 & 36 & 13 \\
\hline \multirow[t]{5}{*}{$\mathrm{VO}(\mathrm{L})_{2}$} & Acetonitrile & 6 & 21 & 70 & 50 & 19 & 29 \\
\hline & Chloroform & 6 & 10 & 64 & 61 & 30 & 29 \\
\hline & Acetone & 7 & 4 & 38 & 46 & 55 & 50 \\
\hline & DMF & 2 & 11 & 28 & 22 & 70 & 67 \\
\hline & $\mathrm{CCl}_{4}$ & 4 & 8 & 57 & 68 & 39 & 34 \\
\hline
\end{tabular}

${ }^{\mathrm{a}}$ The oxidation of cis-cyclooctene $(1.0 \mathrm{mmol})$ by an aqueous $\mathrm{H}_{2} \mathrm{O}_{2}(3.00 \mathrm{mmol})$ or TBHP $(1.5 \mathrm{mmol})$ catalyzed by VO-complexes $(0.01 \mathrm{mmol})$ in $10 \mathrm{~mL}$ solvent for $16 \mathrm{~h}$

${ }^{\mathrm{b}}$ The residual amount of the reactant, cis-cyclooctene

${ }^{\mathrm{c}}$ The other side products are listed as in Tables 5 and 6 
$\mathrm{VO}(\mathrm{acac})(\mathrm{L})$ and $\mathrm{VO}(\mathrm{L})_{2}$ was investigated and summarized in Table 9. Under the optimized reaction conditions, chloroform, acetone, DMF ( $N, N^{\prime}$-dimethylformamide) or carbon tetrachloride was subjected to cis-cyclooctene and an aqueous $\mathrm{H}_{2} \mathrm{O}_{2}(3.0 \mathrm{mmol})$ or TBHP. The results in Table 9 illustrate that the conversion and control chemoselectivity are high influenced by the nature of solvent. With an aqueous $\mathrm{H}_{2} \mathrm{O}_{2}$, acetonitrile is the most effective solvent $(70 \%$ catalyzed by $\mathrm{VO}(\mathrm{acac})(\mathrm{L})$ or $\left.\mathrm{VO}(\mathrm{L})_{2}\right)$, whereas, with TBHP, carbon tetrachloride and chloroform afforded the highest amount of epoxy product (Table 9) (87 and 68\% catalyzed by $\mathrm{VO}(\mathrm{acac})(\mathrm{L})$ or $\mathrm{VO}(\mathrm{L})_{2}$, respectively). In other solvents (DMF and acetone), the epoxidation yields were low for both oxidants and catalysts.

Although, the high coordination ability of acetonitrile [5, 35, 38, 39], it is still the best solvent for the epoxidation processes due to its high resistant for oxidation. The high dielectric constant of acetonitrile could improve the catalytic potential of $\mathrm{H}_{2} \mathrm{O}_{2}$ $[22,31-33]$, this is why acetonitrile is the best solvent for the epoxidation reaction using an aqueous $\mathrm{H}_{2} \mathrm{O}_{2}$, as resulted in Table 9.

Oppositely, the most effective solvent for using TBHP as the oxidant is carbon tetrachloride and chloroform as reported previously [11, 35, 38-41] (Table 9). The inability of carbon tetrachloride and chloroform with low dielectric constant to coordinate to the central metal ion could be the reason to improve the catalytic yield of the epoxidation process.

\section{The mechanistic aspects}

Several mechanistic pathways have been proposed for the (ep)oxidation of alkenes catalyzed by oxovanadium complexes with alternative visions [22, 42]. Here we try to summarize the most convenient mechanism of the catalytic (ep)oxidation of alkenes. Despite, $\mathrm{V}^{4+}=\mathrm{O}$ species are relatively stable toward oxidation, they may be easily oxidized to $\mathrm{V}^{5+}=\mathrm{O}$ species, as active species $[20,22]$, in the presence of a suitable oxidant homogeneously and heterogeneously [41]. Therefore, the mechanism of (ep)oxidation catalytic reactions are performed by the type of oxovanadium(IV) complexes [5] and is strongly depending upon the oxidant, e.g. $\mathrm{H}_{2} \mathrm{O}_{2}$, via formation of a peroxide intermediate complex with the VO-catalyst, or through coordination of $\mathrm{ROO}^{-}$anion of alkylhydroperoxides $\mathrm{ROOH}$ to the central metal ion $[26,42]$. The effect of the oxidant on the catalytic potentials of the VO-complexes has been evaluated by monitoring their UV-Vis. spectral changes, cyclic voltammeteries [43] or the electrochemical behavior of VO-catalysts in the catalytic processes $[17,25,32,33]$. The treatment of either an aqueous $\mathrm{H}_{2} \mathrm{O}_{2}$ or TBHP to the VO-complex solution in acetonitrile in presence of cis-cyclooctene causes an observable shift of the characteristic maximum absorption band of the L-MCT band [33] (Fig. 4).

Such shift could be observed from 409 to $388 \mathrm{~nm}$ and from 400 to $352 \mathrm{~nm}$ for $\mathrm{VO}(\operatorname{acac})(\mathrm{L})$ and $\mathrm{VO}(\mathrm{L})_{2}$, respectively. These shifts are accompanied with changing in color from greenish brown to dark yellow and from green to yellow for $\mathrm{VO}(\mathrm{L})_{2}$ and $\mathrm{VO}(\mathrm{acac})(\mathrm{L})$, respectively (Figs. 5, 6) without no observable changes in the absorption bands at 248 and $232 \mathrm{~nm}\left(\pi \rightarrow \pi^{*}\right)$ and 275 and $277 \mathrm{~nm}\left(\mathrm{n} \rightarrow \pi^{*}\right)$ of $\mathrm{VO}(\mathrm{L})_{2}$ and $\mathrm{VO}(\mathrm{acac})(\mathrm{L})$, respectively (Fig. 4). This change could be due to the 


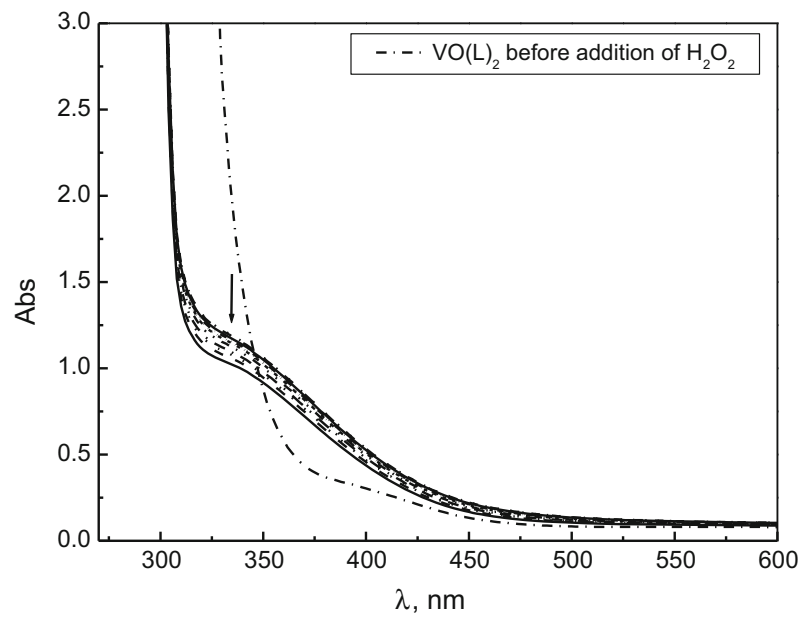

Fig. 5 Visible spectral scan changes of $\mathrm{VO}(\mathrm{L})_{2}$ with cis-cyclooctene before and after addition of an aqueous $\mathrm{H}_{2} \mathrm{O}_{2}$ to cis-cyclooctene in acetonitrile at $45^{\circ} \mathrm{C}$ with interval time $15 \mathrm{~min}$ for $2.5 \mathrm{~h}$

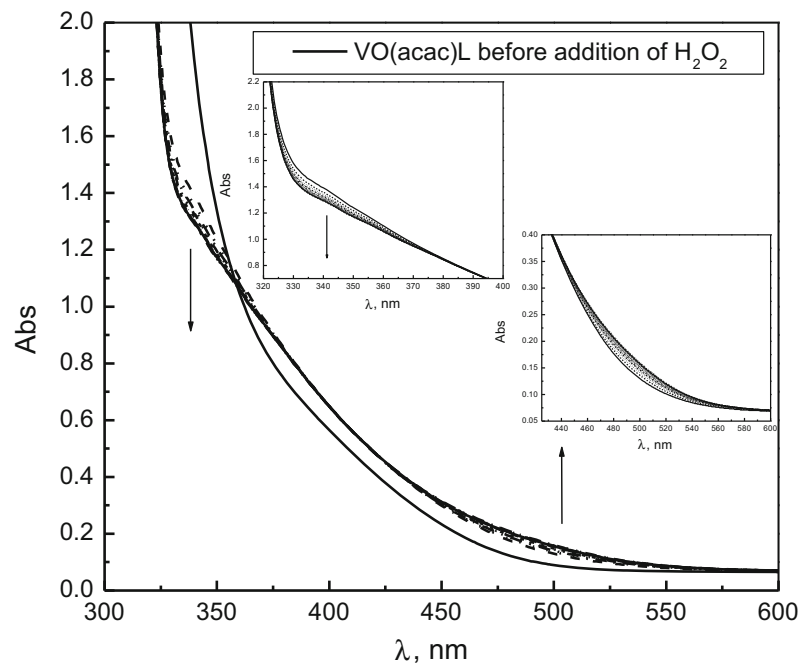

Fig. 6 Visible spectral scan changes of $\mathrm{VO}(\mathrm{acac})(\mathrm{L})$ with cis-cyclooctene before and after addition of an aqueous $\mathrm{H}_{2} \mathrm{O}_{2}$ to cis-cyclooctene in acetonitrile at $45{ }^{\circ} \mathrm{C}$ with interval time $15 \mathrm{~min}$ for $2.5 \mathrm{~h}$

oxidation of the central metal ion from $\mathrm{V}^{4+}=\mathrm{O}$ to $\mathrm{V}^{5+}=\mathrm{O}[42,43]$ in agreement with the most previous reported studies [32, 33, 44-46] affording $\mathrm{V}^{5+}$ with $\mathrm{d}^{0}$ electronic configuration, i.e. high electrophile. Particularly, the resulted band decays in the (ep)oxidation proceeded by time, as shown in Figs. 5 and 6. Fig. 6 shows an isosbestic point at $419 \mathrm{~nm}$ for the pseudo first order reaction.

The first oxidation step in the tentative mechanism (Scheme 4) was suggested by the interaction of peroxo group of the oxidant, $\mathrm{H}_{2} \mathrm{O}_{2}$ or TBHP with the $\mathrm{V}^{4+}=\mathrm{O}$ central metal to give an active $\mathrm{V}^{5+}=\mathrm{O}$ intermediate complex through an electron 


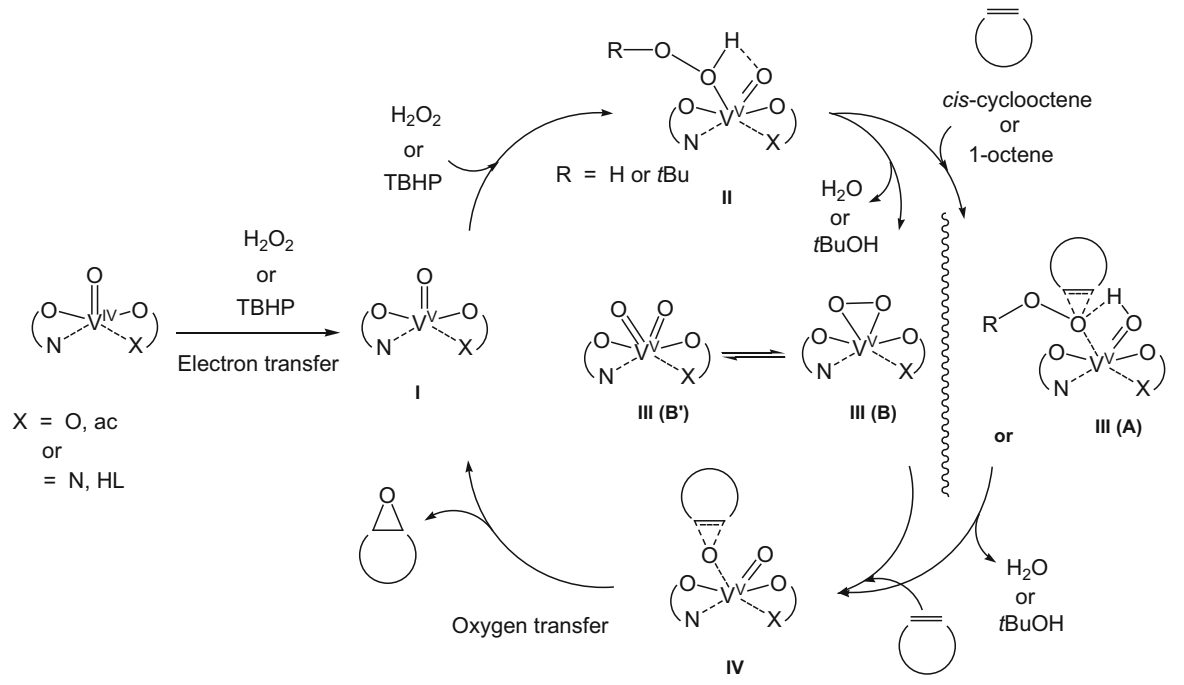

Scheme 4 The mechanistic aspects of the epoxidation of cis-cyclooctene or 1-octene using either an aqueous $\mathrm{H}_{2} \mathrm{O}_{2}$ or TBHP catalyzed by $\mathrm{VO}(\mathrm{acac})(\mathrm{L})$ or $\mathrm{VO}(\mathrm{L})_{2}$

transfer [47] from the catalyst to the oxidant (species I), as reported by Monfared et al. [11] and by Maurya et al. [33] This causes an observable shift of the characteristic maximum absorption band of the L-MCT band, as mentioned above, which is followed by an interaction between the active $\mathrm{V}^{5+}=\mathrm{O}$ intermediate species, as electrophiles. Then, another $\mathrm{H}_{2} \mathrm{O}_{2}$ or TBHP molecule to give an oxo-peroxo intermediate complex (species II), as suggested by Rayati et al. [32] and Bisht et al. [33]. The oxo-peroxo intermediate complex (species II) could be formed due to coordination of an oxidant molecule, as a nucleophile (with high electron density on the oxygen atom), to the active $\mathrm{V}^{5+}=\mathrm{O}$ oxo-peroxo intermediate (species I), as well reported elsewhere [30, 42]. It followed by an approach of the substrate (ciscyclooctene or 1-octene) to the coordinated oxidant giving a new oxo-peroxo intermediate (species III A) resulted from the interaction of the $\mathrm{V}^{5+}=\mathrm{O}$ with the coordinated oxidant, $\mathrm{V}^{5+}=\mathrm{O}-\mathrm{H}$ [48], as suggested by Grivani et al. [26, 33, 35] and Rayati et al. [43]. However, with mass spectroscopic detection by Bortolini et al. [42], another proposed pathway for the reactivity of species II was suggested by removal of a water or tert-butyl alcohol $(t \mathrm{BuOH})$ molecule to give a new peroxo intermediate complex (species III B) [30, 49]. The peroxo intermediate species III B could be in an equilibrium with dioxovanadium intermediate complex (III B') [21, 30, 42]. Both intermediates (III B and III B') could be formed due to oxygen transfer step [20]. The presence of III B' could be more acceptable for $\mathrm{VO}(\mathrm{acac})(\mathrm{L})$ due to the presence of a high reactive acetylacetonate ligand $[20,50]$. The presence of III B could be more acceptable for $\mathrm{VO}(\mathrm{acac})(\mathrm{L})$ due to the presence of a high reactive acetylacetonate ligand $[20,50]$. This suggestion has been studied by Nunes et al. [41] in the epoxidation of styrene by $\mathrm{H}_{2} \mathrm{O}_{2}$. DFT calculations suggest that an intermediate of $[\mathrm{VO}(\mathrm{H}-\mathrm{BIAN})(\mathrm{MeOO})]^{+}$contains active $\mathrm{V}^{\mathrm{IV}}$ species in two proposed competitive mechanisms. Furthermore, the 
donor atom electrochemical contribution to redox potentials (DEC) of the $\mathrm{O}_{\mathrm{ac}}$ (acetylacetonate-enolic oxygen) compared to $\mathrm{N}_{\text {py }}$ (pyridine nitrogen) in the square pyramidal vanadyl complexes is an important study to measure the VO-complexes reactivity toward catalytic oxidation processes as reported by Keramidas et al. [51] and by our previous work $[52,53]$. This could be a highly acceptable reason for the higher catalytic activity of $\mathrm{VO}(\mathrm{acac})(\mathrm{L})$ compared to $\mathrm{VO}(\mathrm{L})_{2}$ in the (ep)oxidation processes of cis-cyclooctene or 1,2-octene homogeneously.

One involves an external attack of the olefin at the coordinated peroxide, and the second involves an inner sphere mechanism by coordination of the olefin to $\mathrm{VO}^{2+}$ ion. This suggested mechanism involves replacement of acetylacetonate ligand by the nucleophilic oxidant, i.e. $\mathrm{H}_{2} \mathrm{O}_{2}$ with coordination to the central metal ion. The decay in the intensity of the characteristic maximum absorption band could be resulted from the oxygen transfer $[22,54]$, i.e. oxygenation, from the species IV to the approached substrate in order to be oxidized forming the chemoselective product (epoxy-1,2-cyclooctane or epoxy-1,2-octane) and other products with regeneration of the active species I (Scheme 4). Finally, the probability for the replacement of the reactive acac ligand by the oxidant molecule could be not supported here as detected elsewhere [33, 54], because the small difference in the reactivity and catalytic sufficiency between $\mathrm{VO}(\mathrm{acac})(\mathrm{L})$ and $\mathrm{VO}(\mathrm{L})_{2}$ is not high remarkable.

\section{Conclusion}

1,3-Dipyridin-2-yl-urea as a ligand reacts with $\mathrm{VO}(\mathrm{acac})_{2}$ forming two novel ternary and binary mono-oxovanadium(IV) complexes depending upon the ratios of ligand to metal, 1:1 in $\mathrm{VO}(\mathrm{acac})(\mathrm{L})$ and 1:2 in $\mathrm{VO}(\mathrm{L})_{2}$. They are characterized by EA, IR and UV-Vis Spectra, conductivity and magnetic measurements. The calculated formation constants $K_{f}$ from the spectrophotometric measurements show that $\mathrm{VO}(\mathrm{acac})(\mathrm{L})$ is less stable than $\mathrm{VO}(\mathrm{L})_{2}$. The catalytic (ep)oxidation of ciscyclooctene and 1-octene by an aqueous hydrogen peroxide, $\mathrm{H}_{2} \mathrm{O}_{2}$, and tert-butyl hydroperoxide, TBHP, as oxygen sources, is studied in the presence of either $\mathrm{VO}(\mathrm{acac})(\mathrm{L})$ or $\mathrm{VO}(\mathrm{L})_{2}$, as a homogeneous catalyst, within effects of temperature, solvent and oxidant/alkene molar ratio are studied in order to get the optimized reaction conditions. The chemoselective product of cis-cyclooctene (ep)oxidation is epoxy-1,2-cyclooctane and for 1-octene, the chemoselective product is epoxy-1,2octane. The side products of the catalytic (ep)oxidation of cis-cyclooctene determined qualitatively and quantitatively by GC-Mass which are 4-cyclooctene1-one, cyclooctanone, cyclooctane-1,2-diol, 2-cyclooctene-1-one and 2-hydroxycyclooctanone, a side products. For 1-octene, the side products are 7-octen-2-one, 2-octenal, 1-octanoic acid, 1,2-octanediol and octanal. The increase of the catalyst amount to double time reduces the (ep)oxidation process time with improvement of the amount of the chemoselective epoxy product. The electronic effect of the coordinated ligands in $\mathrm{VO}(\mathrm{acac})(\mathrm{L})$ and $\mathrm{VO}(\mathrm{L})_{2}$ has an impact on their catalytic potentials by the yield of the chemoselective products of the (ep)oxidation of ciscyclooctene and 1-octene. The type of oxidant, an aqueous $\mathrm{H}_{2} \mathrm{O}_{2}$ and TBHP, effects on the amount of the (ep)oxidation yield of the chemoselective products, in which 
TBHP is more reactive than an aqueous $\mathrm{H}_{2} \mathrm{O}_{2}$ due to the aqueous hydrolysis ring opening reaction. The mechanistic pathway is suggested and shows an electron transfer from the oxidant to the catalyst forming an active intermediate of $\mathrm{V}^{5+} \mathrm{O}$ species which is detected spectroscopically.

Acknowledgements The authors greatly thank Prof. Dr. Usama El-Ayaan, Professor of Inorganic Chemistry, Chemistry Department, Faculty of Science, Mansoura University, Mansoura-35516, Egypt his continued and precious advice and encouragement to produce this work.

Open Access This article is distributed under the terms of the Creative Commons Attribution 4.0 International License (http://creativecommons.org/licenses/by/4.0/), which permits unrestricted use, distribution, and reproduction in any medium, provided you give appropriate credit to the original author(s) and the source, provide a link to the Creative Commons license, and indicate if changes were made.

\section{References}

1. Pessoa JC, Etcheverry S, Gambino D (2015) Coord Chem Rev 301-302:24-48

2. Kioseoglou E, Petanidis S, Gabriel C, Salifoglou A (2015) Coord Chem Rev 301-302:87-105

3. Willsky GR, Chi L-H, Godzala M, Kostyniak PJ, Smee JJ, Trujillo AM, Alfano JA, Ding W, Hu Z, Crans DC (2011) Coord Chem Rev 255:2258-2269

4. Jakusch T, Pessoa JC, Kiss T (2011) Coord Chem Rev 255:2218

5. da Silva JAL, da Silva JJRF, Pombeiro AJL (2011) Coord Chem Rev 255:2232-2248

6. Pessoa JC (2015) J Inorg Biochem 147:4-24

7. Pourkhosravani M, Dehghanpour S, Farzaneh F, Sohrabi S (2017) Reac Kinet Mech Cat 122:961-981

8. Adam MSS, Youssef MM, Aboelghar MF, Hafez AM, El-Ayaan U (2017) Appl Organomet Chem. https://doi.org/10.1002/aoc.3650

9. Bezaatpour A (2014) Reac Kinet Mech Cat 112:453-465

10. Back DF, de Oliveira GM, Roman D, Ballin MA, Kober R, Piquini PC (2014) Inorg Chim Acta 412:6-14

11. Hosseini-Monfared H, Bikas R, Mayer P (2010) Inorg Chim Acta 363:2574-2583

12. Cabeza JA, del Rio I, Martinez-Mendeza L, Miguel D (2007) J Organomet Chem 692:4407-4410

13. Barboiu M, van der Lee A (2003) Acta Crystallgr C C59:m366-m368

14. Meng S, Tang Y, Yin Y, Yin X, Xie J (2013) RSC Adv 3:18115-18127

15. Kyriakidou F, Panagiotopoulos A, Perlepes SP, Maessi-Zoupa E (1996) Polyhedron 15:1031-1034

16. Tiliakos M, Cordopatis P, Terzis A, Raptopoulou CP, Perlepes SP, Manessi-Zoupa E (2001) Polyhedron 20:2203-2214

17. Mandal M, Nagaraju V, Karunakar GV, Sarma B, Borah BJ, Bania KK (2015) J Phys Chem C 119:28854-28870

18. Thompson KH, Bohmerle K, Polishchuk E, Martins C, Toleikis P, Tse J, Yuen V, McNeill JH, Orvig C (2004) J Inorg Biochem 98:2063-2070

19. Job P (1928) Ann Chem 9:113-203

20. Adão P, Pessoa JC, Henriques RT, Kuznetsov ML, Avecilla F, Maurya MR, Kumar U, Correia I (2009) Inorg Chem 48:3542-3561

21. Sutradhar M, Martins LMDRS, da Silva MFCG, Pombeiro AJL (2015) Coord Chem Rev 301-302:200-239

22. Licini G, Conte V, Coletti A, Mba M, Zonta C (2001) Coord Chem Rev 255:2345-2357

23. Santos ICMS, Gamelas JAF, Duarte TAG, Simoes MMQ, Neves MGPMS, Cavaleiro JAS, Cavaeiro AMV (2017) J Mol Catal A 426:593-599

24. Lal RA, Chakrabarty M, Choudhury S, Ahmed A, Borthakur R, Kumar A (2010) J Coord Chem 63:163-175

25. Sedighipoor M, Kianfar AH, Mahmood WAK, Azarian MH (2017) Inorg Chim Acta 457:116-121 
26. Schoenfeldt NJ, Ni Z, Korinda AW, Meyer RJ, Notestein JM (2011) J Am Chem Soc 133:18684-18695

27. Maurya MR, Bisht M, Avecilla F (2011) J Mol Catal A 344:18-27

28. Lashanizadegan M, Rayati S, Zeinab DD (2011) Chin J Chem 29:2439-2444

29. Yuan LS, Razali R, Efendi J, Buang NA, Nur H (2013) Appl Catal A 460-461:21-25

30. Conte V, Coletti A, Floris B, Licini G, Zonta C (2011) Coord Chem Rev 255:2165-2177

31. Adam MSS (2015) Monatsh Chem 146:1823-1836

32. Rayati S, Ghaemi A, Sadeghzadeh N (2010) Catal Commun 11:792-796

33. Bisht MRM, Kumar A, Kuznetsov ML, Avecilla F, Pessoa JC (2011) Dalton Trans 40:6968-6983

34. Coletti A, Galloni P, Sartorel A, Conte V, Floris B (2012) Catal Today 192:44-55

35. Grivani G, Tahmasebi V, Khalaji AD, Fejfarova K, Dušek M (2013) Polyhedron 51:54-60

36. Asadi Z, Zeinali A, Dusek M, Eigner V (2014) Int J Chem Kinet 46:718-729

37. Abdel-Rahman LH, Abu-Dief AM, Adam MSS, Hamdan SK (2016) Catal Lett 146:1373-1396

38. Grivani G, Khalaji AD, Tahmasebi V, Gotoh K, Ishida H (2012) Polyhedron 31:265-271

39. Grivani G, Bruno G, Rudbari HA, Khalaji AD, Pourteimouri P (2012) Inorg Chem Commun 18:15-20

40. Ghaffari A, Behzad M, Dutkiewicz G, Kubick M, Salehi M (2012) J Coord Chem 65:840-855

41. Nunes CD, Vaz PD, Felix V, Veiros LF, Moniz T, Rangel M, Realista S, Mourato AC, Calhorda MJ (2015) Dalton Trans 44:5125-5138

42. Bortolini O, Conte V (2006) Mass Spectrom Rev 25:724-740

43. Rayati S, Ashouri F (2012) C R Chim 15:679-687

44. Joseph T, Srinivas D, Gopinath CS, Halligudi SB (2002) Catal Lett 83:209-214

45. Maurya MR, Chandrakar AK, Chand S (2007) J Mol Catal A 270:225-235

46. Maurya MR, Kumar A (2006) J Mol Catal A 250:190-198

47. Hamstra BJ, Colpas GJ, Pecoraro VL (1998) Inorg Chem 37:949-955

48. Rayati S, Koliaei M, Ashouri F, Mohebbi S, Wojtczak A, Kozakiewicz A (2008) App Catal A 346:65-71

49. Mirzaee M, Bahramian B, Gholizadeh J, Feizi A, Gholami R (2017) Chem Eng J 308:160-168

50. Vlasiou M, Drouza C, Kabanos TA, Keramidas AD (2015) J Inorg Biochem 147:39-43

51. Aschi M, Crucianelli M, Giuseppea AD, Nicola CD, Marchetti F (2012) Catal Today 192:56-65

52. Adam MSS, Abd El-Lateef HM, Soliman KM (2018) J Mol Liq 250:307-322

53. Adam MSS (2018) Appl Organometal Chem. https://doi.org/10.1002/aoc.4234

54. Cussó O, Serrano-Plana J, Costas M (2017) ACS Catal 7:5046-5053 